\title{
Delineamentos para uma teoria da Museologia
}

\author{
Suely Moraes Cerávolo \\ Depto. de Museologia/FFCH/UFBA
}

RESUMO: Os delineamentos para modelar uma teoria para a Museologia foram gerados e divulgados no plano internacional a partir de meados dos anos 80 do século XX e se relacionam com a instauração do Comitê Internacional para a Museologia (Icofom), vinculado ao Conselho Internacional de Museus (lcom). As opiniões sobre a natureza do denominado conhecimento museológico foram sendo emitidas sob condições bastante específicas de composição de grupo e de trabalho intelectual. Embora tenham surgido concomitantemente dificuldades com as palavras e com elas o "problema terminológico", ressaltamos aqui a conjuntura que envolveu tal modelagem: o ambiente, os objetivos, o modo como foi sendo composta, os fundamentos que the caracterizam e algumas discussões ocorridas relevando aspectos que ficaram como herança para essa área de especialidade.

PALAVRAS-CHAVE: Museologia. Icom. Icofom. Museus.

ABSTRACT: The guiding principles in the formulation of a Museology theory were established and disseminated internationally from the mid-1980s, and are related to the creation of the International Committee for Museology (lcofom), associated with the International Council of Museums (lcom). The opinions regarding the nature of so-called museological knowledge were issued under the very specific conditions of each group's composition and of the intellectual work undertook in the occasion. Despite the difficulties with the wording, risen in tandem with the exercise (the "terminology problem"), we focused on the conjuncture that surrounded the formulation: the environment, the aims, the way in which it was composed and the foundations that characterise it, as well as some of the discussions that took place, which revealed aspects that have been handed down as a legacy in this field of specialization.

KEYWORDS: Museology. Icom. Icofom. Museums.

A Museologia como área de conhecimento conta com uma história de formação a ser rememorada. Os delineamentos para a formação de sua 
2. Peter van Mensch explica que o termo museologia não está bem documentado, mas o situa na segunda metade do século XIX na obra de P.L. Martin Praxis der Naturgeschichte, 1869, empregado no sentido de "exposição e preservação de coleções de naturália". Nos dicionários franceses não teria aparecido antes de 1931 e entre os ingleses parece ter sido evitado "exceto por um uso acidental no David Murray's Mu seum, em 1904". A fonte citada por van Mensch é AGREN,P. U. Museologia a new branch of humanities in Sweden? Papers in museology, n. 1, Acta Universitatis Umensis 108 Estocolmo,p. 104-1, 1992. (VAN MENSCH, 1992: The structure of museology: 3 de 7). Segundo Waldisa Rússio, a palavra museologia teria sido usada por J. G. Th. Graesse, em Dresden, numa publicação "entre 1878 e 1883" (Estudos de Museologia e de Antigüidades e ciên cias afins). Rússio e van Mensch referem-se à mesma frase do prováve trabalho de Graesse: "Se alguém falasse ou escrevesse sobre Museologia como ciência, há trinta, ou mesmo vinte anos atrás receberia um sorriso in dulgente e piedoso de grande número de pessoa." Rússio acrescenta com comentário: "Hoje a situação é bastante diversa." (RÚSSIO, 1989, p. 8) Para Rússio havia uma ancestralidade do "fazer museológico" e, além do trabalho de Graesse, referencia um periódico do século XIX (1871) publicado em Madri voltado para museus, arquivos e bibliotecas. Isso lhe dá indicações da preocupação com "temas museológi- teoria foram gerados no plano internacional, no qual encontrou uma maior divulgação, particularmente no decorrer das décadas de 70 e 80 do século XX. Parte dessa história relaciona-se com a instauração de um dos comitês do Conselho Internacional de Museus (lcom), fundado em 1946 e associado à Unesco, o Comitê Internacional da Museologia (lcofom), no ano de 1977, data formal de sua criação'. Revisitar esse período, o ambiente em que essa teoria aflorou, os seus objetivos, o modo como foi sendo composta, os fundamentos que foram the caracterizando e as discussões que a envolveram visa a apontar determinados problemas que permanecem ao se falar sobre Museologia. Algumas publicações desse comitê, como o Icofom Study Series (ISS) e o Museological Working Papers/Documents du Travail Museologique (MuWoP/DoTraM), nos dão essa oportunidade ao situar a maneira como ocorreu a busca para moldar teoricamente a área almejando cunhar pressupostos para suprir o que era tido como um vazio.

ambiente

A Museologia como conjunto de princípios, aflorado no decorrer dos anos 1980, passou a ser sistematizada a partir da reunião de pessoas interessadas em discuti-la, situação essa facilitada ou mesmo possibilitada pela implantação do Icofom, uma iniciativa do tcheco Jan Jelinek. No entanto, isso não significa que a palavra museologia não fosse empregada antes desse período ${ }^{2}$, o que muda são os significados com que passa a ser revestida. $\bigcirc$ generalíssimo sentido de algo condizente a museus ou montagem de exposições foi sendo revisto pelas discussões promovidas pelo comitê, demonstrando que, ao contrário do que se poderia imaginar, a palavra atrela essa ou outras possibilidades de significação.

Após a instauração do Icofom, em razão das concepções já existentes ou em desenvolvimento e também pela possibilidade de disseminação por meio de publicações - que bem ou mal chegaram ao plano internacional -, outras idéias sobre Museologia passaram a se espraiar pelo "mundo dos museus", que têm na edificação sua forma material; sendo assim, como então preencher o nível teórico? Com atividades ou funções? Como ou com quais instrumentos explicá-lo? Tais dúvidas foram levadas para o âmbito do Icofom, e as respostas apresentadas acumulam-se para preencher o vazio apontado. Para aquilo que, afinal, parecia mais se tratar de uma questão de identidade de área, tornou-se conveniente o estabelecimento de conexões entre as dúvidas, a modulação de um conhecimento particular, a explicitação de uma teoria e o apontamento de métodos.

Ora, rever certas passagens ocorridas no Icofom - vamos tomá-lo como ambiente em que se instalaram as palavras da Museologia -, situa-nos num panorama específico. Remete-nos a que veio e a seus objetivos expressos, reapresenta as concepções primeiras decorrentes de um diálogo entre perguntas e respostas, fazendo com que os participantes se posicionassem favoravelmente 
ou não, a alguns fatores, talvez os mais corriqueiros, da forma como foi sendo criada a necessidade de uma Museologia teórica.

Deve-se considerar - e isso não é desprezível - que Museologia como área não se restringe ao lcofom. No entanto, mesmo com outras associações mais antigas e anteriores com o objetivo de cuidar de questões profissionais (como a britânica Museums Association, 1889, e a norte-americana American Association of Museum, 1906) ${ }^{3}$, a abrangência internacional desse comitê sob a égide do lcom e da Unesco sugere a ultrapassagem de fronteiras geográficas. objetivo dessas associações era tratar aspectos profissionais incluindo os de formação, diverso da preocupação com o aspecto científico declarado e procurado pelos participantes do comitê para a Museologia ${ }^{4}$. Esse é o traço distintivo que abre caminho para discussões mais contínuas e internacionais. Considerando-se os trabalhos para os sucessivos encontros anuais, as publicações que thes seguiram, a procedência dos colaboradores e as suas posições - por essa abrangência e penetração, embora houvesse uma heterogeneidade de idéias -, os discursos foram sendo modelados, legitimados pela instância que os produzia, e nós com eles nos familiarizando.

\section{A que veio ou os objetivos}

A instauração de um comitê específico para Museologia foi uma "impressionante aventura intelectual", na expressão da brasileira Tereza Scheiner ao rever o percurso desenrolado pelo lcofom ao longo de mais de duas décadas de atividade. $O$ papel dos participantes desse comitê foi, a princípio, descobrir os conteúdos da Museologia, tarefa abraçada por um "pequeno grupo de idealistas" (Scheiner cita, entre outros, Jan Jelinek, Wolfgang Klausewitz, Andreas Gröte, Irina Antonova, além de Vinos Sofka) que, graças inclusive à ampliação do alcance geográfico de seus quadros, gerou uma produção de "trabalhos universitários" em Museologia teórica. O papel do comitê foi desenvolver pesquisas, análises e debates, contribuindo para a independência da área ${ }^{5}$.

No seu documento constitutivo, as Regras (Rules), essas questões foram estabelecidas ad hoc pelo tcheco Jelinek, dando ao Icofom formatação administrativa e científica. Ele já concebia pesquisas em museus o que correspondia a uma Museologia como disciplina científica provedora do desenvolvimento dos museus e seus profissionais, estudando o papel dos museus na sociedade, suas atividades e funções, de forma a incentivar a análise crítica das principais tendências apresentadas naquele momento. Para corresponder a esses objetivos, o primeiro programa trienal tratou da pesquisa, das relações entre museus, instâncias governamentais e outras fontes de financiamento, e suas relações com outras instituições culturais. Jelinek argumentava ${ }^{6}$ que a Museologia deveria ser estudada para se desenvolver e se adaptar às mudanças de seu tempo da mesma forma que outras atividades profissionais. $\bigcirc$ papel do lcofom seria o de funcionar como "consciência" do $\mid \mathrm{com}^{7}$. cos", à época, dirigido para colecionadores (RÚsSIO, 1989, p.8).

3. cf. BAGAHALI, S. A.; BAOYLAN, P; HERREMAN,Y., 1998.

4. Para o próprio Icofom o comitê desenvolve pesquisas científicas. Martin R. Schärer declara: "Após longos anos de pesquisas científicas, o Icofom tem o prazer de apresentar [...]" (SCHÄRER. 1995). Um outro exemplo é dado por Vinos Sofka em 1984: "Atividades científicas são um traço permanente dos encontros do comitê Internacional para a Museologia do Icom." (SOFKA, 1995, p. 6).

5. SCHEINER, 2000, p. 2.

6. Essa argumentação é apresentada num documento de van Mensch. The establishment of a new international committee on museology. In ternational Committee for Museology, 1992, $3 \mathrm{e}$ 4 de 20.

7.VAN MENSCH, id. ibid. 
8. BELLAIGUE, 2000 , p. 4.

9.A Museologia foi situada entre as Ciências Sociais a partir da Mesa-re donda de Santiago, Chile, em 1972 (SCHEINER, 1989 , p. 60; BELLAIGUE, 2000, p. 4)

10. SCHEINER, 2000, p. 3

11. Peter van Mensch di vide a história do Icofom em três períodos: Pré-história; o Primeiro período, 1977-1982; e o Segundo período, 1983-1989. Os marcos escolhidos para tal periodização foram os tchecos Jan Jelinek e Vi nos Sofka, considerados como "personalidades fortes" (VAN MENSCH.International Committee for Museology, 1992, 1 a 4 de 20).

12. SCHEINER, 2000, p. 2.

13. BOYLAN, P. J., 1996 , p. $47-50$.

14. SCHEINER; BELLAIGUE; VAN MENSCH, 2000.

15. SCHEINER, 2000.

16. BELLAIGUE, 2000 ,p. 4 .

17. SOFKA, 1995.
O grupo de origem tinha como tarefa fazer do museu um objeto de estudo e legitimá-lo como nova disciplina acadêmica. $\bigcirc$ objeto de estudo, no entanto, deslocou-se transferindo-se de uma Museologia de museus para a "relação específica do homem com a realidade" (na concepção de ZbyněK Z. Stránský e Anna Gregorová "fato museal" segundo Waldisa Rússio) ou como uma relação mediadora entre homem e patrimônio (BELLAIGUE, 2000) modificando-the o perfil, abrindo-the portais de interpretação. Nesse processo, abraçou e incorporou aquilo que surgia como conceitos novos - ecomuseologia, "nova museologia", "museu total". As mudanças ocorrem em direção ao que Bellaigue descreve como ênfase na dimensão social e política, a "museologia social", envolvendo um objeto museal, assim o denomina, amplificado8.

A Museologia foi, então, percebida como "ciência em nascimento", interdisciplinar; tomou emprestado metodologias das ciências do homem e da sociedade e acabou sendo atrelada às Ciências Sociais e à Filosofia, diz a francesa Matilde Bellaigue?. Passou a ser vista como fenômeno, o que the possibilita incluir as mais diversas manifestações e as mais variadas formas, "[da] institucional à realidade virtual", completa Scheiner ${ }^{10}$. Lá se vão 28 anos de mudanças, se contarmos a partir do ano de criação (1976) do comitê, que já tem uma história dividida em períodos".

Inicialmente, as idéias sobre Museologia foram norteadas por um duplo propósito: reforçar o fato de que museus são importantes para $\circ$ desenvolvimento social como fontes potenciais de informação e conhecimentos (SCHEINER, 2000) e introduzir ou reforçar os "estudos de museu" dentro das universidades. Essas tarefas eram consideradas ambiciosas, envolvendo por sua vez duas investigações: o estudo teórico dos museus e a Museologia como campo de conhecimento com definições, metodologia e sistema determinado essa era a intenção. A formulação desse sistema viria legitimá-lo como disciplina universitária fazendo-se necessário esclarecer-the os seus limites, identificando suas fronteiras para perceber e, assim, evidenciar as inter-relações com outras disciplinas, entre elas a Filosofia do Conhecimento, Antropologia Social e Cultural, Ciências do Ambiente, Ciências Políticas e Ciência da Informação ${ }^{12}$. Assim, tendo os museus de um lado, e os cursos em universidades e preocupações com a preparação profissional de outro, o Icofom melindrou as fronteiras do Comitê Internacional para Treinamento de Pessoal em Museus (ICTOP), instalado em 1968, para cuidar de assuntos da "profissão museística", na palavra do inglês Patrick Boylan ${ }^{13}$.

A publicação regular de documentos por parte do lcofom, desde 1978, foi fundamental para o nascimento ou construção ${ }^{14}$ daquilo que hoje se conhece como uma "teoria do museu", a "museologia como disciplina acadêmica"15 e, também, para a divulgação do que estava sendo concebido. No ano de 2000, Bellaigue, retomando a história desse comitê, afirma que seu objetivo maior foi "estudar os aspectos teóricos dos museus"l6, ativados por meio de seus programas trienais. Esses programas determinam as diretrizes dos trabalhos a serem desenvolvidos. Nos idos de 1980, sob a direção deste "cidadão sueco de origem tcheca" tal como se apresenta Vinos Sofka", os 
programas passam para longo prazo $^{18}$ firmando um bem-sucedido modus operandi, com base num planejamento coordenado de simpósios, conferências, oficinas, publicações e exposições, sendo o ponto alto o simpósio anual, momento de discussões e debates diretos. A respeitabilidade do lcofom como plataforma de discussões teóricas foi construída por essa rede de atividades que se complementam umas às outras e, em 1988, a Museologia chega ao auge, uma afirmativa que Sofka reforça tomando como base o volume de documentos produzidos ${ }^{19}$.

Os programas trienais formavam a rota traçada para organizar as atividades do comitê indicando temas previamente escolhidos por assuntos de interesse - o que nos diz que os debates partiam de pontos determinados -, como também arquitetavam e dinamizavam, na visão de Sofka, a esperada estrutura científica. Nessa estrutura, pretendia-se cuidar de aspectos teóricos e metodológicos, tendo em vista o objeto de estudo da Museologia e aspectos práticos, com vários focos: as atividades dos museus, as suas funções na sociedade, as tendências e novidades, o papel do profissional de museu em crise de identidade pela participação cada vez maior de profissionais com as mais diversas formações, etc.

Assim, com uma freqüência de fundo - identificar a Museologia -, o lcofom não escapava de, para delimitar suas fronteiras externas diante de outros comitês (pense-se no ICTOP), trazer para o seu plano interno discussões sobre uma teoria que the mostrasse a face de ciência, incorporando o viés prático e problemas de seu tempo para the dar a face contemporânea do lado profissional. Dessa junção, fundindo uma face na outra, formou-se uma cadeia particular de conexões, que articulava intelectualmente a esperada teoria para uma prática secular, mas que, naqueles tempos, já atestava forte mutação, não mais limitada ou conformada aos quadros de museus tradicionais presos às suas coleções que esperavam ser visitadas por indivíduos contemplativos ou a pesquisas levadas a cabo por curadores sobre objetos guardados em museus.

que comumente é denominado "pensamento museológico" foi sendo gerado por essas programações e registrado nas publicações do lcofom. Anteriormente ao comitê já havia reflexões na direção da atomização da área, mas tratava-se de pontos isolados ${ }^{20}$. Com o grupo interessado em levar adiante a discussão - aqueles que abraçaram a causa - formou-se o "cérebro"21, com ampla predominância de europeus do Leste $^{22}$, o que marcou fortemente um modo de conceber a Museologia.

Pode-se dizer que, se a palavra museologia não era novidade e os museus uma inovação, os "idealistas combatentes" buscaram autonomia disciplinar questionando direta ou indiretamente a ambos, fazendo assomar dúvidas a partir de provocações, como se expressou Sofka, um desses idealistas, tido por Martin R. Schärer como um dos "pais, arquiteto e pater familias" responsável pela formação da comunidade do lcofom ao redor do mundo ${ }^{23}$.

Para Sofka, em sua análise retrospectiva sujeita aos caprichos da lembrança ${ }^{24}$, o lcofom além de ser um "oásis" - um espaço para intercâmbio de idéias, encontro de pessoas, agregando indivíduos do Leste e Oeste europeus,
18. A política de ação do Icofom para firmar o programa de longo alcance (Long-term programme) baseava-se no documento Icofom aims \& policy indicando em cada período trienal programas trienais (Triennial programme) (VAN MENSCH. International Committee for $\mathrm{Mu}$ seology, 1992, 3 e 4 de 20).

19. SOFKA, 1995, p. 8.

20.VAN MENSCH, 1992.

21. VAN MENSCH. International Committee for Museology, 1992,13 de 20.

22. Em 1986, de 30 membros foram eleitos três do Leste Europeu para o comitê. Peter van Mensch vê entre 1977-1989 uma mudança gradual na predominância de socialistas e "francófonos" e "anglófonos". Os participantes do grupo nuclear do Icofom entre 1983-1989 foram: Sofka (Suécia); van Mensch (Holanda), Bellaigue (França), Šola (Iugoslávia), Spielbauer (EUA), Desvallées (França), Schreiner (antiga RDA), Stránský (Tchecoslováquia), Carrilo (Espanha), Morral (Espanha), Gorte (RFA), e Kaplan (EUA) (VAN MENSCH. International Committee for $\mathrm{Mu}$ seology, 1992: 13 de 20).

23. Martin R. Schärer era presidente do Icofom ao convidarVinos Sofka para apresentar suas rememorações sobre os primeiros anos desse comitê, a quem é dedicada a reimpressão de 1995 dos cadernos do Icofom Study Series - ISS. (SCHÄRER. Foreword, 1995, s.n.)

24. Sofka aceitando o convite de Martin Schärer para escrever"algumas reminiscências sobre sua venturosa vida com o Icofom e a Museologia" (no original trata-se de frase interrogativa), diz mais à frente que concordou em es- 
crever não um estudo histórico ou pesquisa ou aná lise crítica. Sua contribuição para a história do Icofom deveria ser sua "própria bistória" (my own story) (em itálico no original), falando sobre "suas próprias idéias, reflexões, reações, observações e ex periências, tal como delas se lembrava". (SOFKA, 1995, p. 2).

25.SOFKA; op.cit.,p. 14-15

26. O percurso profissional de Sofka foi iniciado com o diploma de advogado (1952), almejando carreira diplomática sem futuro nas condições em que vivia o seu país. Tornou-se pedreiro, depois chefe de trabalhos administrativos no Instituto de Arqueologia na Academia de Ciências da Tchecoslováquia em Brno (1956) Chega à "museologista", não sabe "se por sorte ou fatalidade" e em razão de seu envolvimento com "museus, museologia e museologistas". Declarase um deles:"Sou иm mu seólogo" (I am museologist), metamorfoseado pelas circunstâncias inespe radas do acaso pelo falecimento do vice-presidente de um grande evento. A convite de instâncias governamentais passa a responder pela conclusão de uma exposição itinerante, tendo a missão de acompanhá-la. A exposição tornou-se um modelo, e ele um especialista - "o único especialista nesse cam po na Academia [de Ciências]". As portas para o exterior se abriram dandolhe duas chances: a de trabalhar e trocar idéias, o que lhe parece tão caro, com profissionais de outras áreas (cientistas, arquitetos, artistas, produtores, educadores, entre outros), e também de conseguir um emprego em algum museu no exílio. A exposição passa a ser as sociada a Sofka como"sua exposição" ("my exbibi- sem "suspeita, desconfiança, e descrença", com espírito de compreensão, tolerância e amizade, e no qual era possível estabelecer objetivos em conjunto -, gozava, nesse período, de uma situação relativamente livre, talvez porque "cuidava de assuntos que não eram classificados como de especial importância ou perigosos", ao mesmo tempo em que se firmava como um corpo profissional de especialistas. Os museus, no seu entender, tinham espaço de ação, mas ainda deveriam ser convencidos de que a instituição e as coleções poderiam ser melhor e mais eficientemente usadas como recursos socioculturais. Algo como uma memória potencial e estoque de experiências, em suas palavras.

Sobre o desenvolvimento da Museologia, esse "personagem pai" o vê como uma busca por suas "essências e [...] conceitos, [a] relação do homem, sociedade e seu mundo, e [com] a herança cultural e natural", uma visão holística, completa. $\bigcirc$ comitê via a Museologia como uma base teórica para o trabalho de museu e para o staff qualificado. $\bigcirc$ grupo interessado não ia além de "20 ou 25 pessoas", e estratégias foram postas em ação para aumentar o número de participantes ${ }^{25}$.

Os museólogos desse período surgiram quase por acaso, resultantes de uma metamorfose, expressão usada por Sokfa referindo-se à sua transformação num deles ${ }^{26}$. Essa profissão vinculada aos museus brotou entre curadores e técnicos. Profissão apreensível no caminho das práticas, do fazer e executar, aparecendo sem carreira, resultado de uma modificação, gerou um profissional mutante - um estranho, uma nova variedade -, mescla de formações e habilidades. Sofka foi só um exemplo dentre outros ${ }^{27}$.

Opiniões ou perguntas e respostas

De acordo com Peter van Mensch um "estoque de teoria museológica" para firmar-se como disciplina acadêmica desenvolveu-se desde os anos $1960^{28}$. Se essa idéia, expectativa ou desejo já assomava alguns, digamos, pensadores da Museologia, eles estavam dispersos, fato relativamente superado com a instauração do lcofom. Houve, a partir dessa concentração, a modelagem de certo núcleo de idéias que, embora tomassem até rumos contrários, formou um conjunto de referências relativamente mais estáveis e conhecidas.

Com a institucionalização do lcofom, agregaram-se pessoas, europeus na sua maioria, reunidas para responder a uma pergunta da qual Vinos Sofka presidente do lcofom de 1977 a 1989 - parece ter se tornado o porta-voz. Pergunta simples, ele escreve em vários textos: "o que é Museologia?"

Uma pergunta que não veio só, pois envolvia outras interrogações simultaneamente: qual sua identidade como disciplina acadêmica e sua consistência?; qual sua estrutura científica própria?; qual a relação entre essa estrutura e outros campos de pesquisa e a que áreas estaria relacionada?; qual, afinal, seria a identidade da profissão? ${ }^{29}$ As respostas mostraram que a pergunta não era assim tão simples e se estava longe do consenso. Se, por ventura, a 
palavra sugeria um sentido unívoco, a possibilidade de debate expôs sua condição polissêmica.

Para se chegar a certo corpus sobre o que tratava ou deveria tratar a Museologia, questionários ou pequenos sumários se tornaram um meio para obter respostas fazendo com que os participantes e colaboradores se posicionassem nos encontros internacionais ou nacionais do lcom e lcofom.

Em 197530, o dinamarquês Villy Toft Jensen realizou um levantamento entre alguns profissionais de museu por meio de questionário para obter um painel da situação específica (da Dinamarca), que ainda não contava com um treinamento formal em Museologia, mas que vinha intensificando debates sobre o assunto. $\bigcirc$ questionário - um levantamento de opiniões - baseava-se nos tipos de treinamento nos países e perguntava qual era, ou poderia ser, o conceito de Museologia neles adotado ${ }^{31}$. As perguntas procuravam verificar as razões do crescimento, quer do treinamento em Museologia em universidades, quer das atividades do lcom.

Observe-se que, nas questões, estavam presentes interrogações plantadas anteriormente pontuando problemas que acabam sendo mais condensados e explorados nos textos das publicações do ICOFOM, MuWoP/ DoTraM ou do ISS. Perguntava-se sobre os conteúdos e direções teóricas da Museologia, sobre a situação de independência ou inter-relacionamento com outras disciplinas, seu método ou métodos. As dúvidas envolviam o estatuto da Museologia como ciência autônoma ou como resultado de uma somatória de disciplinas específicas representadas nos acervos dos museus. $\bigcirc$ que não era posto em questão, nesse período, era o museu como base para tal ciência, situação que mudará alguns anos mais tarde. Esse levantamento mostrou, segundo a opinião de Vinos Sofka, "quão grande era a confusão sobre [o que é] museologia"32.

A forma de intercâmbio, com base na redação e envio de respostas para o presidente do comitê (nesse período Sofka), seguia um roteiro prévio de perguntas. As respostas, textos escritos não muito longos, abertas a réplicas, levavam cada autor a opinar sobre o material enviado por algum outro colaborador, passando pelo conselho do comitê ${ }^{33}$.

Nos roteiros iniciais (citamos o roteiro enviado para o encontro em Londres, 19831), podem-se inferir os níveis de interesse a respeito da Museologia abarcando o seu objeto de estudo (em outras passagens "objeto de conhecimento"), as características desse conhecimento, os seus objetivos e métodos. $\bigcirc$ pré-requisito era identificar o objeto da Museologia (item 1) mesmo que dele não houvesse formulação definitiva, de acordo com uma recomendação de Sofka: "o autor pode simplesmente dizer o que entende por museologia de forma a não deixar dúvidas na mente do leitor. Também não é necessário defini-la longamente" ${ }^{\prime 35}$.

Os itens eram decompostos em alternativas, o que indica ou sugere que havia pontos problemáticos de alguma forma compartilhados; tratava-se, portanto, de um problema latente. Lembre-se que as opiniões de muitos autores tion") (itálico e aspas do autor), (SOFKA, 1995, p. 3-6).

27. Cita-se a professora Waldisa Rússio Guarnieri, cuja formação inicial foi em Direito, fundadora do curso de Museologia na FESP/SP.

28. Peter van Mensch cita publicações ou reuniões da década de 60, 70 e 80 cujo objeto de discussão era a Museologia como disciplina acadêmica. A primeira seria do tcheco Jiri Neustupny, em 1968 , na forma de um manual sobre trabalho em museu. De 1976 em diante, o Icofom teria tido um papel fundamental nessas discussões. Cita, ao lado das publicações, o simpósio realizado pelo Departamento de Museologia da J. E. Purkinje University (depois Universidade de Masaryk, em Brno, 1965); duas conferências realizadas pelo Comitê Nacional Germânico em 1971 e 1988 (VAN MENSCH. The museology discourse 1992, 1 de 14).

29. VAN MENSCH, The museology discourse, 1992, 9 de 14; The structure of museology, $1 \mathrm{de}$ 7; e Professionalism and museology: 1 de 11. Sobre a emancipação da Museologia como disciplina acadêmica conectada com o processo de profissionalização dos trabalhos de museu (The museology discourse, 1992, 1 de 14).

30. Segundo van Mensch, dez anos antes (1965), Stránský já havia coletado entre pessoas que trabalhavam em museus respostas sobre se a Museologia poderia ou não ser considerada uma disciplina acadêmica (VAN MENSCH. The museology discourse, 1992:10 de 14).

31. Foram enviados 140 questionários em inglês, francês e alemão para di- 
ferentes profissionais de museus, cujos nomes foram obtidos entre os participantes da conferência do Icom realizada em Copenhague, em 1974. Foram recebidos 70 questionários respondidos de 10 países, sem que o autor os cite (ao menos nesse trabalho da $M u W o P$ ). Jensen considera que 50 vieram com respostas "bem detalhadas", e mesmo sem representatividade estatística, as respostas, porque advindas de pessoas conside radas de grande influência sobre o "futuro desenvolvimento museológico", deviam ser levadas em consideração (JENSEN 1981).

32. SOFKA. $M u W o P, \mathrm{n} .1$, p. 6 .

33. SOFKA, 1995, p. 8.

34. Nesse encontro agendado para ocorrer no encontro geral do Icom, houve debates sobre a intersecção entre o Icofom e o ICTOP. Dois temas foram propostos por Jan B. Cuypers (do ICTOP): um sobre a metodologia da $\mathrm{Mu}-$ seologia e treinamento profissional, outro sobre o Tratado de Museologia, teorias museológicas e o futuro da profissão. Sofka presidente interino do Icofom, aceita e escolhe o primeiro tema, que sugere ressaltar aspectos "mais importantes e significantes para os dois comitês", em nome de uma causa comum - o aperfeiçoamento da profissão por meio do estudo teórico da Museologia e do treinamento. O tema do encontro versou sobre a metodologia da Museologia e o treinamento profissional. (SOFKA, 1995)

35. SOFKA, 1995 , p. 8

36. Id. p. 8-9

37. Os autores que contribuíram para com os Basic Papers e Comments em desses documentos já haviam sido publicadas em 1981 e 1982 na MuWoP, material a que recorriam avalizando suas opiniões.

Sobre a natureza do conhecimento museológico (item 2), o ponto de partida era uma afirmativa. O conhecimento museológico e a perícia museográfica cobriam um largo campo, a interrogação vinha a seguir e desmembrada em alternativas: seria ele conhecimento científico, filosófico, prático, técnico, habilidade manual ou outro? $O$ próximo ponto (item 3) procurava explorar a composição do conhecimento museológico e por quais campos seria formado. Essa questão foi desdobrada em mais duas perguntas; a primeira era dirigida para a constituição do sistema da Museologia e como considerar as relações interdisciplinares entre a Museologia e esses diferentes campos. $\mathrm{Na}$ segunda uma série de sugestões perguntando se elas deveriam ser incluídas no campo de conhecimento lexpressão seguida no texło por "conhecimento científico" entre parênteses) e postas no mesmo nível. Foram suas sugestões, pontuadas e colocadas em seqüência: o conhecimento da Física, Química e Bioquímica (conservação); o conhecimento histórico (com história dos museus, desenvolvimento dos museus, etc.); a Museologia teórica e filosófica tendo entre parênteses a indicação da teoria da educação em museus, etc.; a Sociologia e Psicologia como estudo do comportamento individual e de grupo dos visitantes, terminando por um "etc." e reticências, sugerindo a abertura para que os interessados incluíssem suas opiniões.

No que se refere aos objetivos do conhecimento científico (item 4) solicitava, em primeiro lugar, que se distinguisse entre objetivos da Museologia e os da pesquisa museológica e entre os do ensino e treinamento. Uma afirmativa, sem explicações, acompanhava a questão: "Os objetivos do conhecimento museológico determinam seus métodos". O ponto seguinte (item 5) chamava para a diferenciação de métodos entre o da Museologia, o da pesquisa museológica, os de ensino e treinamento. Por fim (item 6), questionava se haveria uma metodologia, ou várias, e qual a relação que teria com o treinamento profissional em Museologia ${ }^{36}$.

Nas respostas, seguindo esse roteiro, os colaboradores ${ }^{37}$ procuraram delinear um objeto próprio de conhecimento, qualificado como museológico, na busca de explicar melhor um campo que foi sendo identificado resignificando uma palavra que, diferentemente de museografia, teve criador e data ${ }^{38}$. As respostas iam explicitando a área menos pelas certezas do que pelas dúvidas, mas surgia alguma coesão tecida ao redor do tema Museologia, embora nele houvesse fissuras.

Segundo van Mensch, carecia-se de trabalhos de síntese e conclusões, o que nos indica uma produção intelectual esparsa e de difícil acesso, fato que desencadeou "fallhas de continuidade na participação", produzindo a sensação de contínua reinvenção já que, para cada simpósio, o ponto de partida parecia ser sempre o mesmo. Ele tece o comentário de que "cada conferência produzia um novo material, mas não havia uma estratégia para a construção de uma casa" ${ }^{\prime 39}$, porém nem por isso deixa de firmar a importância desse comitê na divulgação da Museologia e a íntima paridade entre sua história como disciplina acadêmica. 
Nesse delineamento, com o intento de organizar a Museologia como corpo de conhecimentos ditos científicos, surgiu imediatamente a tensão entre "práticos" e "teóricos", situação demonstrada nos documentos deixados ou relatos posteriores (VAN MENSCH, 2001 ; SCHEINER, 2000; BELLAIGUE, 2000). Os conteúdos das respostas enviadas foram sendo concebidos por estímulos até antagônicos.

Havia os "a favor" de uma Museologia-museu instituição - a dimensão mais tangível, material, dotada de presença social - e os que se colocavam "contra", procurando escapar da referência física, o museu edificação. Estes imaginaram que ela se encontrava para além das atividades diárias no trato com as coleções ou com montagem de exposições.

Chegaram a uma Museologia-patrimônio, ampla, extensa, abarcando o mundo e saindo das paredes que parecem the confinar ${ }^{40}$. Contra ou a favor, a validade da instituição não foi posta em dúvida, e as opiniões, mesmo que contrárias, visavam a um único objetivo: prover, com uma forma determinada de pensamento chamada de teoria, aqueles que trabalhavam nos museus ou que ministravam e estudavam nos cursos universitários.

$\bigcirc$ investimento intelectual representava assim um ganho bem prático. Conformar a Museologia como ciência, mesmo que ligada ou não à instituição museu, fundamentava a profissão, dava-lhe identidade. Especificar suas características, descrevê-la, enfim trazer à luz o seu objeto de estudo, no entanto, era algo que escapava, movia-se. Situação que, de imediato, trouxe consigo dificuldades para lidar com conceitos que estruturassem também os argumentos dessa área.

Para um mesmo roteiro de perguntas (como o exemplo citado), as respostas se apoiavam ora no que era mais próximo e conhecido - a prática, entendida como trabalho "de museu" - ora, ao inverso, em abstrações, procurando, por meio do estabelecimento de proposições, fundamentar certo raciocínio para dar encaixe à Museologia.

Parte das respostas advinha de reflexões sobre experiências do dia-adia dos colaboradores, observando-se o que era tido como um vazio ou desvio de lugar que a denominação de museólogo ou "museologista" pretendia preencher, sem que houvesse muita certeza do que realmente essa figura incorporava, fazia ou deveria fazer.

Tais dificuldades foram geradas pelo fato de que, numa mesma instituição, alguns não se identificavam com o papel de curadores ou pesquisadores de áreas já mais delimitadas, como Arte, Arqueologia ou História, mesmo que a sua formação básica tivesse sido realizada numa dessas disciplinas; tendo trabalhado diretamente com a montagem de exposições em museus, perguntavam a si mesmos, ou eram por outros questionados, se eram "pesquisadores de museu".
1983 , seguindo o roteiro de conteúdos foram: G. Ellis Burcaw (Moscou; EUA); Wojciech Gluzinski (Wroclaw: Polônia); Sadashiv Gorakshkar (Bombaim: Índia); John Hodge (New South Wales: Austrália); Ilse Jahn (Berlim:República Democrática Alemã); Peter van Mensch, Piet J. M. Pouw e Frans F. J. Schouten (Leiden: Holanda); Kwasi Myles (Acra: Gana); S. M. Nair (Nova Déhi:Índia); Waldisa Rússio (São Paulo: Brasil), Zbynek Stránský (Brno: Tchecoslováquia). Os sumários e análise dos documentos em preparação para o simpósio foram realizados por Judith K. Spielbauer (Oxford: EUA). Rosario Carrilo (Madri: Espanha) está citada na lista de contribuintes para o colóquio (ISS, n. 1, 1995, p. 1/4).

38. A palavra Museographia é dada como título de uma obra de C. F. Neickel do século XVIII (1727), escrita em latim "para assegurar sua difusão em toda a Europa”. Um tratado teórico com orientações sobre classificação, ordenação, conservação de coleções e referências sobre salas de exposição, orientação da luz, distribuição dos objetos artísticos e dos espécimes de história natural (cf. HERNÁNDEZ citando como fonte dessa informação: SCHLOSSER, Las cámaras artísticas y maravillosas del renacimiento tardio. Edit.Akal/Universitaria. Madrid. 1988, p. 222) (HERNÁNDEZ, 1998, p. 64 65,308).

39.VAN MENSCH. International Committee for Museology, 1992, 14 de $20 ; 13$ de 20 .

40. Francisca H. Hernández cita comentário do sociólogo francês HenryPierre Jeudy no qual diz que diante de tantas possibilidades "o mundo poderia converter-se num gi- 
gantesco museu", deixando entrever que isso seria um risco (HERNÁNDEZ, 1998, p. 69-70)

41. Para Matilde Bellaigue, o nível filosófico da $\mathrm{Mu}$ seologia foi alcançado pelos museólogos do Leste europeu onde nasceu o Icofom e nutrido por experiências dos ecomuseus e museus comunitários desenvolvidas particularmente na França e Canadá (BELLAIGUE, 2000, p. 4) Há diferenças na forma de conceber museus e $\mathrm{Mu}$ seologia se a perspectiva for européia ou norte-americana.

42. Acreditamos que não é possível divorciar nem as alterações e desdobramentos na forma e noção de museu nem de Museologia como disciplina das mudanças sociais e culturais que remexeram o sé culo XX, como aponta o historiador Eric Hobs bawn (1995). De acordo com David Harvey, ocorreu uma mudança na "estrutura do sentimento" que se tornou o traço singular da pós-modernidade. A produção cultura foi atingida pela lógica do poder de mercado, uma decorrência do capitalis mo avançado. Essas mudanças chegaram aos museus da seguinte maneira uma "cultura de museu" desenvolveu-se com base numa "indústria da heranca", utilizando a comercialização da história e outras formas culturais. Cultura e mercado fundem se numa simbiose frenética.A questão do consumo torna-se basilar para a mudança de hábitos e atitudes desenvolvidos principalmente pela classe média. São tempos marcados pela rapidez na produção de bens e respostas aos desejos de consumo, e muito passa a emanar da chamada cultura e consumo de massa, atingindo mais do que manifestações artísticas. No seu en-
Nesse aspecto, fazia-se coincidir o ato de montar exposições com algo próprio deste personagem, o museólogo, e, como extensão quase que natural, com esta Museologia nascente. Outros, para explicá-la, ministrando cursos de formação profissional na área, tomavam as práticas como teoria, fazendo rodopiar suas reflexões sobre o mesmo eixo, o da prática.

As propostas, mesmo com a tendência européia de imprimir ao tema direções mais filosóficas ou teóricas, diferentemente do pragmatismo norteamericano ${ }^{41}$, não deixavam de ser instrumentais, no sentido de dar a esse "novo" campo elementos formais para a auto-reflexão.

Essa bipolarização criada entre prática e teoria nos convém, mesmo que houvesse composições entre uma e outra, pelo fato de sublinhar que refletir sobre Museologia representou um investimento maior sobre sua natureza, parece que com avanços após a institucionalização do lcofom. Essa construção era conveniente para a melhor identificação profissional ou para facilitar e dar sustento a sua inserção nas universidades, permeando a profissionalização de uma roupagem científica antes não existente, ou ainda mais frágil. Os que se dedicaram a essas reflexões procuraram, ainda que apoiados no tão velho e conhecido museu, afirmar sua importância rompendo com essa base para também escapar da direção impressa pelo senso comum que toma a Museologia como equivalente a algo que acontece, se faz ou se apresenta dentro dos museus.

Considerada desnecessária ou imprescindivel, essa Museologia oscilou - e isso nos ficou como herança - em algum ponto da trilogia formada por esteios diferentes: instituição, profissão e ciência. $\bigcirc$ objeto "museu" parecia certo e cristalizado, mas nem ele se mantinha o mesmo. A prática, como fazer diário, também se renovava e dela profissionais de várias áreas participavam cada vez mais. Como chamá-los? Por sua vez, as questões como, o que e onde atuar se ampliaram enormemente. $\bigcirc$ museu não era mais o mesmo.

As mudanças que os museus tiveram eram atribuídas às conseqüências ou efeitos do "mundo moderno", datados no pós-guerra, e ao reflexo do movimento de modernização com o qual se defrontaram nos inícios dos anos 1970, alinhados, assim, com as injunções daquele momento histórico ${ }^{42}$.

Admitindo-se que os museus se encontravam num estado de evolução e considerando-se as suas modificações no momento durante e pós instauração do lcofom (dos anos 1970 em diante), tem-se um movimento efervescente, uma outra etapa. Nas bordas dos anos 1980, eles já haviam deixado de estar vinculados unicamente à pesquisa, exceto pela exposição de peças, embora para alguns essas tarefas permanecessem fundamentais.

$\bigcirc$ próprio lcom chama a atenção de seus membros para responder e incorporar as inovações. Falava-se em transformações graduais ou radicais, novos métodos de ação, novas atividades decorrentes do uso das coleções, consideradas elos entre passado e presente. Mas esse não é o único ponto em transformação. Tentam-se explicações para o movimento paralelo que comprime, de fora para dentro e no sentido inverso, as mudanças dos museus.

As tendências apontaram para um alargamento da noção de museu, uma alteração das práticas do cotidiano, envolvendo cada vez mais profissionais 
de várias áreas, e a profissionalização em curva ascendente; um envolvimento cada vez maior com a sociedade em geral - expandindo-se "como cogumelos", numa expressão interessante de Peter van Mensch -, um aumento das perspectivas de que se entendessem como prestador de serviços e, portanto, com maiores preocupações para com o público; uma incorporação de estratégias administrativas, de publicidade e marketing para o gerenciamento institucional e captação de verbas na forma de financiamentos, etc.

Segundo a análise de van Mensch, ocorrem novas formas de interesse, integração e relacionamento entre instituição e sociedade, e dessa para com os museus. Há uma série de tendências observáveis: o surgimento de outros tipos de museus (como "móveis", "descentralizados"); um outro tipo de colecionador gerado fora dos grupos da elite cultural e da ação de empresas comerciais, formando coleções e criando museus de corporações; a conservação in situ valorizando o meio físico e contexto original do objeto e desses nascendo os museus de sítio, casas históricas, cidades-museu, ao lado de centros de interpretação do patrimônio cultural, centros de estudos urbanos, etc. Mas há ainda outras tendências como a conceitualização na medida em que se trabalha com tema(s); a ampliação de objeto museológico atrelada à noção expandida de Patrimônio e influenciada por estudos desenvolvidos pela Antropologia com respeito à noção de Cultura. Uma outra tendência dirigia-se para a formação de museus de menores dimensões mais do que grandes instituições nacionais e tradicionais. Outras mudanças atingiam o âmbito interno dos museus tocando os aspectos administrativos e incorporando a racionalização da gestão e autogestão participativa na contratação de mão-de-obra terceirizada e na declarada busca por financiamentos, marketing e publicidade ${ }^{43}$. Passa-se a empregar expressões como "museu-mercado" e "indústria museística"; as coleções tornam-se "capital ativo" particularmente ao se tratar de exposições temporárias ${ }^{44}$. Esse quadro inclui a preocupação crescente com a captação de público - meta a ser atingida, foco de pesquisas de recepção -, demonstrando a intersecção das atividades dos museus com mídias e, por extensão, com a comunicação de massa.

Um outro grande viés, a grande tendência, se podemos chamá-la assim, foi a de tirar os museus do confinamento das famosas "quatro paredes" que até então the davam forma. Fervilhavam, portanto, muitas alterações no plano das idéias e da ação, embora não atingissem todas as instituições. As tendências observadas, geradas antes dos anos 1980, precisavam de terreno propício para se instalar, e esse terreno não era qualquer um. Algumas necessitavam de estruturas organizacionais complexas e sofisticadas, outras dependiam de verbas generosas, de pessoal técnico preparado ou da composição de pessoal de museu com profissionais de outras áreas associados por sua vez a grupos comunitários interessados, e assim por diante. Havia museus preocupados com artefatos e espécimes naturais, mas também aqueles preocupados com um sentido amplo de herança cultural e natural. tender, essas mudanças, acionadas nos anos 60 tornam-se hegemônicas nos 70. Harvey cita as cifras crescentes de abertura de museus na Inglaterra (um museu era aberto a cada três semanas) e no Japão "mais de 500 foram abertos nos últimos quinze anos" (HARVEY, 1989 p. 64-65). O tratamento da história seria "uma criação contemporânea, antes um drama e uma re-representação de costumes do que discurso crítico" (aspas do autor) (HEWISON apud HARVEY, p. 65). Difícil é pensar que essa Museologia dos anos 80, concebida por homens, estivesse - coisa pensada e criador - descolada do espírito do seu tempo, assim como imaginar que a instituição mudasse por si, sem lembrar que foram eles, vivendo nessas décadas, os seres atuantes dentro ou ao lado dos museus.Vale lembrar como afirma van Mensch que a Museologia se fez por pessoas (VAN MENSCH, Object of knowledge, 1992, 2 de 11). Diga-se, um pequeno grupo de pessoas, homens e mulheres.

43. VAN MENSCH, 1989a, 1989b, p. 22.

44. HERNÁNDEZ, 1998,p $70,77-79$. 
45. M.Araújo e M. C. Bruno, reapresentando uma série de documentos produzidos em 1958 (Seminário Regional da Unesco sobre a função educativa dos museus; Rio de Janei ro); 1972 (Mesa-redond de Santiago do Chile); 1984 (Declaração de Quebec) e 1992 (Declaração de Caracas), consideram que havia uma série de expectativas enfrentadas pelos profissionais de museus em seu cotidiano convergindo para uma preocupação em comum, a do papel social dos museus (ARAÚJO; BRUNO, 1995, p. 5)

46.VAN MENSCH. Object of knowledge, 1992, $1 \mathrm{de}$ 11.

47. Embora apresentando o ambiente do Icofom como aberto às discussões $\mathrm{e}$ sublinhando a importância do trabalho em equipe, Sofka não deixa de comentar na sua rememoração o quanto havia para ser realizado, a pouca participação e como sua ação foi solitária (SOFKA, 1995)

48. Sofka relata que seu "affair"com a museologia iniciou-se em 1969, desde seu trabalho no Museu de Antigüidades em Estocolmo (itálico e aspas do au tor) (op. cit.,14).A versão dos fatos no relato de Sofka é a de que em 1978 as inquietações a respeito do que vinha ser Museologia eram seus "questionamentos privados" (SOFKA, op. cit., p. 12/5)

49. SOFKA; 1995 , p. 5/7

50. O que Sofka declara como sua inquietação van Mensch relata que já havia sido apresentada por outras pessoas anteriormente caso de Jan Jelinek (VAN MENSCH. Interna tional Committe for $\mathrm{Mu}$ seology, 1992, 1 e 2 de 20).
As idéias se espalhavam. As margens do que se compreendia por museu, objeto de museu e Museologia foram alargadas de um modo não experimentado anteriormente ou não experimentado tal como então se esboçava.

O mapeamento da Museologia assentava outras tantas dúvidas: seria ela um conjunto de idéias, princípios, métodos de trabalho ou, então, somente técnicas de trabalho? Esse nascimento veio cheio de perguntas, mas com um objetivo certo: defender uma área particular com conhecimentos também particulares.

Reconheciam-se a tradição de trabalho de museus protagonizada pelas tarefas práticas e, em convergência, as mutações sobre o papel social dos museus ${ }^{45}$. Por outro lado, os pontos não concordantes recaíam sobre o perfil da Museologia. A reflexão européia iniciada em focos e dialogada entre poucos expandiu-se, o lcofom para van Mensch reabre e não abre as discussões ${ }^{46}$. As diferenças surgidas, congregadas em linhas, permitem falar em mais de uma Museologia após algum tempo.

Conceber Museologia, ou o dito pensamento museológico que the dá forma, partia, como vimos, de pontos diferentes. As raízes dessas concepções podem ser acompanhadas numa de suas figuras representativas - Vinos Sofka que não só compartilhou da formação do lcofom e o presidiu por boa temporada, como exerceu a função de editor de publicações (o ISS e o MuWoP/DoTraM). Nesse papel liderou, agrupou e conseguiu que fossem publicadas as respostas sobre o que se pretendeu como a natureza da Museologia. Mesmo recebendo as dúvidas como legado de seu antecessor (Jan Jelinek), Sofka encontrou apoio no lcofom e alguma cooperação entre os participantes do comitêt ${ }^{47}$.

Por essas razões o tomamos como um caso emblemático.

Onde buscar os fundamentos para a teoria ou uma forma de conceber a Museologia

Coordenando o gerenciamento e execução de uma grande exposição sobre a literatura eslovena (declarada World Commemorative Year pela Unesco em 1963) que continha muitos "elementos do trabalho em museu", e pressionado pela necessidade de concretizá-la em pouco tempo, Sofka percebeu que, para que fosse realizada, seria necessário uma "base filosófica e teórica para a bemsucedida comunicação e ação da equipe" 48 . Posteriormente, em suas atividades cotidianas exercendo funções administrativas no Museu Nacional de Antigüidades (Estocolmo; Suécia), deu-se conta como "museologista [museólogo] da necessidade de uma teoria na prática do trabalho em museu"49.

Não era somente sua a inquietação $0^{50}$ sobre a falta da base lfilosófica e teórica) da Museologia, outros profissionais que trabalhavam em museus se questionados também demonstravam sua ausência ou a necessidade de tê-la definida. Sofka observou isso nas reuniões do lcofom e lcom, o que o levou a mobilizar-se para a aplicação de questionários. 
Observe-se que Sofka afirma, num plano subjacente, a importância de um conjunto de conceitos e significados mais precisos para determinadas palavras (a começar por Museologia). Isto é, ele expressa a necessidade de circundar o vocabulário da profissão, a linguagem de especialidade, a ser partilhada com pessoas envolvidas nas sucessivas etapas de trabalho (fosse ou não de montagem de uma exposiçãol, de modo que compreendessem e, principalmente, agissem e executassem ações numa mesma e única direção. Assim apresenta-se a dimensão comunicativa que usa palavras - moedas de intercâmbio ágil - para responder às necessidades muito pragmáticas de como resolver lides funcionais, fazendo com que as empreitadas chegassem a bom termo. $\bigcirc$ que Sofka tinha em mente era uma "museologia de palavras", evidentemente instrumental.

Nas suas declarações, "filosofia" sugere equivalência com "teoria" para referir-se a um modo similar de raciocínio, nesse caso pragmático, formando uma base, a Museologia, capaz de cerzir as diferenças de entendimento. Ele a concebe também pragmaticamente para fins de trabalho operacional le harmônicol e não como um sistema de enunciados e conceitos. À medida que essa base ficasse elucidada, serviria inclusive para os cursos de formação das escolas e universidades.

Quanto à própria formação profissional, não deixa de ser curioso o elenco de habilidades ao qual atribuiu o sucesso de seus trabalhos, para que, como museólogo, cumprisse sua tarefa. Elas formavam uma somatória de todos os aprendizados e experiências por que passara: desde o senso sistemático do advogado, que desenvolve posturas e abordagens interdisciplinares, e "métodos gerenciais de administrador, a experiência e habilidades manuais de pedreiro [...] e a sabedoria das pessoas comuns". Esses são os pontos de partida que serviram para a formação de seu "pensamento museológico" 51 , perspectiva partilhada, tal como suas inquietações, por outros colaboradores.

Em sua rememoração, Sofka relata que, mesmo dentro do lcofom, a busca por uma definição de Museologia fora escamoteada ${ }^{52}$, o mesmo sucedendo no lcom. Relata também a existência de um grupo de "antiteóricos" lassim por ele denominados), incluindo no seu depoimento uma passagem que pode nos surpreender, ao apresentar um "irritado George Henri Riviére", que, entre outros aspectos, reclamava que o lcofom tinha estabelecido um programa de pesquisa e iniciado um jornal sem consultá-lo ${ }^{53}$. Dessa forma, tanto as discussões como o aceite dessa Museologia dita teórica ou científica - então numa espécie de equivalência - foram paulatinas.

Numa passagem com certo sabor relata que, no próprio ambiente de trabalho, perguntaram-lhe: "O que é museologia? Nunca ouvi essa palavra!" Ouviu recomendações amigáveis de curadores para que esquecesse "essas excentricidades do continente". Não escapou de exorcismos como: "Proteja-nos da 'museologia' e outras quase-ciências!" A seu juízo, boa parte das confusões advinha do "terminus technicus 'museologia'". Esclarecer esse termo técnico passou a ser, na sua versão dos fatos, uma cruzada intelectual com o fito de "descobrir" a Museologia ${ }^{54}$.
51. SOFKA, op.cit., 5-6.

52. Refere-se ao encontro do Icofom em Moscou, em 1977, no qual, a seu juízo, evitou-se "engenhosamente qualquer definição de museologia" (SOFKA, 1995, p. 11). Posteriormente (1978), num encontro ocorrido na Polônia, onde encontra "pessoas do mundo dos museus" somente o russo Awraam Razgon desenvolve nesse encontro "aspectos museológicos" (outros presentes: Prof. Lorez, Prof. Piotrovski, Dr ${ }^{\mathrm{a}}$. Antonova, Dr. Dabrowxki, Dr. Klausewitz, Dr. Rymaszewski, Villy Toft Jensen) (id., p. 12).

53. George Henri Rivière é considerado uma das figuras eminentes na área de Museologia:"provavelmente a mais importante figura do movimento francês de renovação museológica do pós-guerra, [e] responsável pela criação de muitos museus e ecomuseus na França e em outros países" (BARBUY, 1995 , p. 211). Sofka refere-se ao encontro realizado em Leicester (UK), em 1978 , com o ICTOP (SOFKA, 1995, p. 14-15).

54. A pergunta foi feita pelo diretor do Museum of National Antiquities, Estocolmo.O"exorcismo" parece ter sido lançado pelo editor que convidou Sofka para escrever um artigo em 1976 para um manual sobre técnicas de museu ("Museiteknik", Museum techiques). Quanto à expressão "descobrir" foi usada no subtítulo "Poland 1978 - The autbor calls for an intellectual crusade to discover what museology is "If we don't kbown - if we have doubts - the we find out!" (itálico e aspas do autor),(SOFKA, 1995,p. $7 / 15 ; 12$ ). 
55.Van Mensch apresenta os seguintes dados: em 1990 um questionário aplicado no encontro de Leicester resultou: $90 \%$ dos participantes consideravam a Museologia disciplina independente; para $4 \%$ como disciplina, ela "não fazia sentido" (VAN MENSCH,The museologi cal discourse, 1992, $10 \mathrm{de}$ 14). Esse autor não explica qual a posição dos $6 \%$ faltantes.

56. VAN MENSCH, The museological discourse, 1992, 10 de 14

57. Deve-se registrar que o estatuto dos membros do Icom em termos "profissionais e sociais" foi objeto de preocupação des de a década de 1970 . Em vista da evolução dos museus, o reconhecimento de novas especializações e diversificação de servi ços e demandas, o órgão se vê diante de uma análise"das relações existentes entre os profissionais de museu e seus colegas de outras profissões, científicas ou de ensino". Uma enquete foi prevista para ser desenvolvida pelos comitês nacionais e internacionais, Centro de Documentação e Secretariado para compreender o estatuto e o papel dos profissionais dos museus, cujos focos seriam: formação profissional em todos os níveis de especialização; coleta de dados sobre os centros de formação profissional; reconhecimento da formação universitária pelas autoridades dos diversos países. Uma outra meta visava à publicação de manuais para tratar de vários aspectos da formação profissional. Dessa idéia nasce o projeto para o Tratado de Museologia, confiado a uma equipe internacional de especialis tas. O Icom desenvolveria os Cadernos técnicos (Cabiers tecniques) a serem publicados pela Unesco e bibliografias especializadas (anuais) em parceria com o Centro Internacio-
Ciência, mas e o objeto de estudo?

Os que acompanharam esse processo de dentro do Icofom - de Sofka a van Mensch - dizem que se passaram anos até que o estatuto de Museologia como ciência fosse aceito e reconhecido dentro do $\mathrm{lcom}^{55}$. Tal reconhecimento se deu graças aos encontros (simpósios e seminários nacionais e internacionais) e publicações. Em meados de 1980, os membros do comitê declararam: "tendo por base a teoria da ciência, ela é uma disciplina científica em estágio embrionário" 56

A instauração do lcofom gerou uma situação singular para tratar de ciência. Como associação internacional de profissionais, estava afinada com os macroobjetivos do lcom $^{57}$ e ao mesmo tempo pretendia funcionar como foro de pesquisa, contando com colaboradores (membros), que não necessariamente eram pesquisadores. A articulação se fazia entre profissionais de museus, na maioria das vezes contando com especialistas, o que não é o mesmo que pessoas dedicadas à pesquisa. $\bigcirc$ comitê não é o lugar da pesquisa nem uma entidade física, mas uma "idéia em ação", posta em movimento por indivíduos que the dão corpo e voz expressando suas concepções. Trata-se de indivíduos em trabalhos no comitê, cuja consonância com os temas submeteu-se às preocupações ou interesses dos então dirigentes do lcofom.

A preocupação com os requisitos acadêmicos (entenda-se a abordagem da Museologia como ciêncial mudou na medida em que a participação dos europeus do Leste estagnou - nas palavras de van Mensch entre 1983-1989 e, paralelamente aumentou a participação de colaboradores de outros países, redirecionando o foco para aspectos sociais das atividades dos museus e Museologia. Tal reorientação se deu à custa de "um estudo mais profundo da estrutura da museologia como ciência", cujo discurso continha o mais "alto grau de abstração" 58 . As revistas MuWoP/DoTraM e ISS, criadas pelo grupo original, representavam a expectativa de se ter nelas, ou por meio delas, um trabalho científico; particularmente, a primeira teria sido um novo começo para o "trabalho científico do comitê", permanecendo, porém, um esforço isolado ${ }^{59}$.

Considerando que, em geral, as pesquisas científicas são sistemáticas, é aconselhável ponderar as críticas realizadas até antes do surgimento do lcofom apontando justamente para a ausência de sistematização. Em 1968, J. Neustupny afirmava que os trabalhos sobre Museologia estavam dispersos, eram desconhecidos, não circulavam, seus autores se igonoravam ${ }^{60}$, estavam circunscritos a certos países e havia barreiras de linguagem para sua disseminação. Naquele momento, a Museologia estava isolada e as idéias confinadas. Foram críticas que van Mensch considera procedentes mais de 20 anos depois. Todavia há outras: a concepção da Museologia como sistema fechado como em Gluzinsky; a ausência de um discurso filosófico-teórico e das 
idéias de outros cientistas que não eram referenciadas nos simpósios conforme Möbius; a falta de uma consciência histórica segundo Stránský, e o fato de que "nunca saiu do chão" um plano sistemático sobre a diversidade de abordagens da Museologia (VAN MENSCH)

Ao mesmo tempo em que arrola essas críticas, o próprio van Mensch põe em relevo o método de trabalho de Sofka como gerador da riqueza documentada, poderíamos completar ${ }^{62}$ - sobre os pontos de vista vitais para a identidade da Museologia como ciência, que ao fim foram surgindo.

Novamente a palavra museologia aparece como fio de ligação também na tessitura das seqüências temáticas dos simpósios atreladas aos programas trienais. Da pesquisa em museus para a inter-relação entre objetos, museus e sociedade, considerados como parâmetros e tratados numa perspectiva mais museológica na versão de van Mensch ${ }^{63}$, têm-se ao menos um demonstrativo de que o caminho para a Museologia como ciência não era de fato retilíneo, mas um composto temático modular.

Se nos guiarmos pela sua declaração, os participantes e colaboradores do lcofom, profissionais e intelectuais, viam-se como cientistas perscrutando o "fenômeno museu": "A comunidade científica (i.e. lcofom) necessita de definições para seu trabalho científico $[\ldots]^{\prime \prime 64}$.

$\bigcirc$ que se procurava sob essas capas de objetivos alardeados - uma teoria para explicar, um conhecimento estruturado, sistemático, validando um possível plano científico - era ao fim e ao cabo a autonomia da Museologia. Esse era o tema, mas capta-se nos entremeios que, pelas vias do lcofom, havia a preocupação em tornar mais profissionalizada uma instituição (os museus) e, ao mesmo tempo, a própria disciplina, Museologia. Posto de outro modo, tornar ofício tanto o saber técnico como o próprio conhecimento teórico da área por meio de um corpo de voluntários bem situados profissionalmente em museus ou em unidades de ensino, mas, note-se, não de pesquisadores profissionais.

Esses membros do lcofom foram convidados, arriscaram-se, como nos conta Sofka, a escrever definições, "pequenos sumários sobre o que cada membro [desse comitê editorial] compreendia pelo termo [museologia]". Ele mesmo diz que não se tratava de "dissertações científicas". A idéia era provocar discussões, encorajar definições ${ }^{65}$. E elas foram provocadas causando, no caminho, incômodo e reações. Afloraram abordagens e modos para compreendê-las, sendo os principais alvos a Museologia como ciência e seu objeto, os museus. Com algo tão palpável como os museus e tão direto como pensar que Museologia a eles se refere, qual a necessidade de problematizar a tal "museologia de museus"?

Considere-se que, ao lado dos objetivos declarados pelo lcofom em estruturar teoricamente a Museologia - o que significava estudá-la para ser ministrada em universidades e para que os profissionais de museu tivessem uma base teórica em suas atividades práticas -, havia mudanças na idéia de museu que não podiam mais ser desconsideradas. Isso afetava diretamente as tentativas de conceituá-la bem como a identificação do seu objeto de estudo. $\bigcirc$ sólido nal de Conservação (Roma). Os comitês regionais seriam encorajados a elaborar publicações de manuais (Rapports d'activités. Programme. Nouvelles de L'Icom. Bulletin trimestriel du Conseil International des Musées, 1974-1980, 25).

58. Houve um "primeiro grupo" que levou as discussões, outros a abraçaram mais "recentemente" (a tese de van Mensch da ta de 1992). Estes últimos não estavam familiarizados com os primeiros escritos dos teóricos. Os tchecos teriam sido os grandes influenciadores, principalmente Stránský que escolheu tópicos de discussão e o nome do jornal (possivelmente o ISS). Os colaboradores do primeiro grupo não tinham problemas com o tema, ou seja, debater a Museologia como ciência, diferentemente dos de outros países europeus que mostravam receio ou respondiam as perguntas superficialmente (VAN MENS $\mathrm{CH}$. International Committee for Museology, 1992, 14 de 20). É possível observar a diferença na construção do discurso - particularmente nas publicações citadas ISS e MuWoP/DoTraM - entre os colaboradores com maior aproximação da questões ditas teóricas bem como as referências bibliográficas, caso de Klaus Schreiner que cita obras publicadas nos países socialistas $(\mathrm{MuWoP} /$ DoTraM n.1, p. 39) e Zbynek Z. Stránský (MuWoP/ DoTraM n.2, p. 70).

59. VAN MENSCH. Inter national Committee for Museology, 1992,14 de 20.

60. J. Neustupny declara em 1968 sua observação sobre o fato de que havia pouco conhecimento dos trabalhos de Museologia, parecendo-lhe que os autores "estão tão profundamente imersos em suas próprias reflexões que 
não estão interessados nas idéias e sugestões de outros. Artigos e livros sobre Museologia são geralmente confinados às idéias de seus próprios autores [...].Entretanto, muitos livros e artigos [... têm sido escritos" (NEUSTUPNY apud VAN MENSCH. International Com mittee for Museology 1992,14 e 15 de 20).

61. NEUSTPUPNY apud VAN MENSCH. International Committee for Museology, 1992, 15 de 20. GLUZINSKI apud VAN MENSCH, MÖBIUS apud VAN MENSCH, op.cit.

62. Sofka enviava aos colaboradores as diretrizes para participar dos simpó sios. Os trabalhos redigidos serviam de eixo par o sucesso dos encontros e material para as publicações (SOFKA, 1983)

63.VAN MENSCH, op. cit. 13 de 20

64. Por "definição" enten de-se em van Mensch: es trutura para caracterizar os museus; a distinção entre instituição e instituto; entre museus como instituição museológica permanente, arquivos e bibliotecas; ou critério (VAN MENSCH, The $m u$ seum definition, 1992, 1 de 8). Tereza Scheiner e Mathilde Bellaigue também creditam ao grupo do Icofom a produção de ciência (cf. SCHEINER, BELLAIGUE, 2000).

65. Os autores que se "arriscaram" a definir museologia foram Villy Toft Jensen; Wolfgang Klausewitz Awraam M. Razgon e o próprio Vinos Sofka. (Mu seological provocations 1979. Four attempts to define the concept of mu seology by the Editorial Board MuWoP,n. 1,p.11 13; SOFKA, Point for Dis cussion: What is Museology? Introduction by the Editor View - Europe 1975. MuWoP, n. 1, p. 6) tripé de uma Museologia dita tradicional, fundamentado no objeto de museu, museu e funções ou atividades do museu, isolados ou entrelaçados, passou a ser questionado pelos adeptos da "Nova Museologia".

\section{Museologias}

Referir-se à Museologia como ciência dentro do lcofom foi uma preocupação que norteou os primeiros participantes. A discussão sobre ela ser vista como ciência dos museus, na voz do norte-americano George Ellis Burcaw, ou como metafísica, no caso do tcheco Tomislav Šola, ao chegar em meados dos anos 1980 se apoiou num conjunto de idéias distribuídas em livros ou artigos publicados em revistas, cujos títulos levavam a denominação de "Museologia" ou "museu". Nesse rol, além da revista Museum (Unesco) ${ }^{60}$, registram-se, em muitos países, revistas específicas sobre o assunto ${ }^{67}$. $\bigcirc$ russo A. Razon afirmava que, nesse período, havia "mais de 600" revistas ${ }^{68}$.

Salientar o objeto de estudo da Museologia representava, à medida que se delimitavam suas fronteiras, atentar para a espécie de conhecimento particular que a diferenciava e a caracteriza de outras áreas, e o grupo de colaboradores focou seus esforços para dominar esse objetivo. Não bastava denominá-la "ciência"; fazia-se efetivo propor teorizações e, estruturando raciocínios, focalizar seu objeto de estudo. Esse seria o fator decisivo para tornála uma "genuína disciplina acadêmica", que surge na medida em que deslindava a "intenção cognitiva da museologia" (VAN MENSCH). Para ser genuína, a disciplina deveria responder a uma necessidade social e identificar sua contribuição para o conhecimento geral e para os que trabalhavam em museus. Em todos os casos, o importante era explicitá-la ${ }^{69}$.

Passamos à síntese e categorização realizada por Peter van Mensch ${ }^{70}$, muito próximo ao comitê, com acesso às fontes e autores que referencia. $\bigcirc$ que segue não exaure as múltiplas seqüências de conceitos sobre objetos de museu, museus e Museologia emitidas nos anos 1980, bem como as inter-relações propostas por aqueles colaboradores. Alguns deles não se furtaram a ajustes de suas próprias concepções, alterando-as ou refazendo-as com o passar dos anos caso, por exemplo, do tcheco Z. Z. Stránský, apontando para o fato de que, se o processo de teorizá-la já havia se iniciado muito antes ${ }^{71}$, o terreno ainda era movediço.

ângulo inicial da Museologia como ciência dos museus foi se abrindo em leque. Surgiram bifurcações, cada uma delas agrupando traços comuns. Stránský preferiu referir-se a elas como "tendências de conhecimento" para a busca do objeto de conhecimento ${ }^{72}$, e van Mensch como "escolas" laspas usadas pelo autor) para dizer da orientação cognitiva da Museologia ${ }^{73}$. Cabe aqui repassar as informações apresentadas por esse autor que nos diz que a 
maioria das publicações sobre teoria da Museologia estava vinculada ao grupo do lcofom. São estes os grupos:

Europa: em 1980, surge "repentinamente" um grupo germânico de teóricos de museus, porém ele não era estruturado e tinha idéias similares inspiradas em autores pós-modernos como Walter Benjamin, Jean Baudrillard, Henri-Pierre Jeudy e Herman Lübbe. Na publicação Die Welt als Museum (1 987), em que o ponto central era o conceito de "musealização", o único autor também participante do Icofom era ZbyneK Stránský. Esse "grupo" (aspas de van Mensch) não participava das atividades do comitê, tendo influência restrita aos falantes de língua germânica em parte da Europa.

Um outro grupo seria formado pelo Departamento de Museums Studies (Leicester University) com forte tendência ao estruturalismo. Pós-moderno, seguia autores como Foucault, Barthes, Bourdieu e era dirigido por Susan Pearce, contando com Eilean Hooper-Greenhill e Gaynor Kavanagh. Assentava-se na idéia de Museologia/atividades de museu. Produzira muitas publicações, entre elas A nova Museologia (The New Museology) em conecção - explícita para van Mensch - com o movimento francês da "nova museologia" Imuséologie nouvelle). Eles não se interessavam, tal como o grupo germânico, pela Museologia como disciplina acadêmica.

Ainda na Europa, van Mensch comenta que, em 1992, não era possível avaliar as conseqüências da "abolição da museologia marxista-leninista".

Estados Unidos: teve maior preocupação com os monumentos e sítios (arqueológicos), gerando e introduzindo termos como "gerenciamento de patrimônio" (heritage manegement) e "gerenciamento de recursos culturais" (cultural resource management), os quais - na expressão de van Mensch - teriam chegado à Europa após um congresso realizado em Southampton (The World Archaeological Congress), em 198674.

Em outra parte de sua tese, ele afirma que o primeiro a discutir o objeto da Museologia foi J. Neustupny em 1950. Após 1965, com as discussões sobre o objeto da Museologia em Brno (Tchecoslováquia), elas proliferaram e se "cristalizaram em poucas bem-definidas escolas de pensamento". $\bigcirc$ francês André Desvallées refere-se em 1987 à "escola tcheca", mas para van Mensch essa denominação não se baseava num conhecimento suficiente da situação na República Tcheca ${ }^{75}$.

$\bigcirc$ que van Mensch agrupa por objeto de conhecimento las tendências de Stránskýl é uma série de perspectivas, geradas a partir de três pontos: o objeto de museu, o museu e as funções de museu. Haveria "museologias"76, já que as perspectivas se alternam e se interseccionam, fazendo brotar outras alternativas, mas que não se afastam muito desse tripé. Dentre os aspectos procurados esperava-se mapear leis que regessem a Museologia ${ }^{77}$.

Articulada sobre o objeto de museu ("herança" recebida), a Museologia seria uma decorrência da aplicação da metodologia dialética-
66. A Museum deu seqüência à Mouseion publicada pela Organização Internacional de Museus na época da Liga das $\mathrm{Na}$ ções (início do século XX).

67. cf. La bonne parole: les revues muséales. $M u$ seum 168 , v. XLII, n. 4 . No Editorial, o redator-chefe Arthur Gillette comenta que dentre 50 títulos resultantes de um inventário provisório, foram selecionados alguns para serem apresentados nesse número da revista. Uma nota sobre a pesquisa de Jacqueline Falk Maggi e Gaël de Guichen informa do pouco noticiário sobre museus na imprensa cotidiana européia.A maioria das revistas é publicada por associações. Não é raro comentarem sobre as dificuldades financeiras os objetivos em geral são voltados para as instituições e profissionais; algumas foram iniciadas no começo do século $\mathrm{XX}$, tiveram sua denominação alterada e sob regimes totalitários foram fechadas e reabertas.

68.VAN MENSCH.The museology discourse, 1992, 1 de 14 .

69.VAN MENSCH. Purpose of understanding, 1992, 1 de 7 .

70. Refiro-me a Object of knowledge e Purpose of understanding (tese, 1992).

71. O primeiro a discutir a natureza do objeto de conhecimento da Museologia foi o tcheco Jiri Neustupny, nos anos 1950. Nos anos 1960 na República DemocrataAlemã, um grupo o definiu como sendo "a totalidade do trabalho em museu", discussão que teve continuidade no primeiro simpósio sobre a teoria da Museologia, ocorrido em Brno em 1965 (Tchecoslováquia). Nele, cf. van Mensch, os participantes 
não chegaram a "qualquer conclusão". Com base num levantamento realizado em 1983 porA.C.Zijderveld, o Icofom procu ra em 1986 num woorks bop (realizado em Berlim e Alt Schwerin) fazer um balanço do "estado de arte" da Museologia (tendo no grupo como convidados: Mathilde Bellaigue, Carrillo,Decarolis, Desvallées, Gluzinski, Jensen, Sofka, Šola, Spielbauer, Schreiner, Stránský, Tsuruta, Grote e o próprio van Mensch). Os resultados desse trabalho nunca foram publicados cf. van Mensch (VAN MENSCH, Object of knowledge, 1992, 1 e 10 de 11).

72. VAN MENSCH, 1994 p. 1

73. VAN MENSCH, Purpose of understanding, 1992, 1 de 7

74.VAN MENSCH. Introduction, 1992, 2 e 3 de 5.

75.VAN MENSCH. Object of knowledge, 1992, 1 e 2 de 11

76. Todos os autores citados por van Mensch são do Leste Europeu: 1950 (Neustupny); 1960 (com autores da República Democrática Alemã); 1966 (com Stránský). De 1970 a 1980, um salto: 1980 (Jensen); 1981 (Benes); 1983 (Gluzinski; Hof mann); 1986 (Schreiner); 1988 (Razgon) (VAN MENSCH. Object of kno wledge, 1992, 1 de 11).

77. (aspas do autor), (VAN MENSCH, Object of kno wledge, 1992, 1 de 11)

78. Um eixo que teria sido iniciado nos anos 1930 (VAN MENSCH. Object of knowledge,1992,2 de 11).

79. Como Arqueologia, Etnologia, História da Arte, e assim por diante, na dependência, num primeiro momento, do tipo de objeto, o que não os exime de serem colocados sob materialista ${ }^{78}$, pela qual os objetos passam a ser vistos como fontes primárias de conhecimento. Nesse caminho, ela choca-se com as chamadas disciplinas de base uma vez que, para estudar esses objetos materiais, recorre-se a outras disciplinas ${ }^{79}$.

Para tentar realizar a secção tendo no horizonte a Museologia, Stránský, por exemplo, propôs o critério de "musealidade" 80 ressaltando o valor documental do objeto ou o objeto percebido como documento, já que representativo de certos valores sociais. Um outro ponto de secção é dado pelo croata lvo Maroevic: a Museologia lidaria com a informação "estocada dentro da estrutura material [da] museália", e não com o objeto em si. Dessa forma, distingue-se a "informação cultural", de interesse da Museologia, da "informação científica" de interesse das disciplinas de base. Contudo, a perspectiva da Museologia-objeto de museu não estancou. Passou para "fenômeno", o que dá a entender uma relação mais ampla sustentada pela noção de patrimônio. O deslocamento se faz do "objeto" para o "valor", e de "objeto de museu" para "patrimônio", segundo van Mensch. O foco vai se extrapolando. Tomislav Šola concebeu uma disciplina denominada "heritologia" açambarcando, sob a Museologia, outras áreas como arquivística, biblioteconomia, preservação histórica ${ }^{81}$.

A Museologia apoiada nas funções dos museus grosso modo corresponderia às atividades específicas também sobre objetos, ou seja, o estudo das atividades de museu ou dos seus trabalhos (SCHIMPFF, 1982), ressaltando o trabalho e profissão como algo próprio e particular de museus, e sua também particular atribuição social, sua missão.

No entanto, permanece a intenção de diferenciar o objeto de museu como fonte original de informação, ou em razão de sua autenticidade, como foco de fenômenos cognitivos (RAZGON) ou fulcro principal de atividades (seleção, preservação, interpretação, investigação, exposição e comunicação): desse apanhado ter-se-ia a compreensão do conhecimento específico da Museologia. Tal visão foi rebatida por llse Jahn com o argumento de que as atividades fariam somente parte da Museologia e não seu objeto primeiro, pois elas poderiam ser desenvolvidas sobre o patrimônio natural e cultural e não somente sobre o objeto de museu ${ }^{82}$.

Seguindo esse raciocínio, haveria uma Museologia "fora dos museus" (VAN MENSCH; POUW; SCHOUTEN, 1983; DELOCHE) ${ }^{83}$. Uma vez aceita tal proposição, outras expressões the seriam mais adequadas - "gerenciamento de patrimônio", "recursos de patrimônio", "recursos culturais" -, as quais significativamente, diz van Mensch, não eram empregadas nos documentos do Icofom, sugerindo-lhe uma falta de alerta para com as "novas tendências no campo cultural"84

Os deslocamentos da rota inicial vão se desdobrando: de Museologia como ciência social, que estuda processos e leis da preservação da informação social e a transferência de conhecimentos e emoções através de objetos, para museus como fenômeno (do ponto de vista histórico) (RAZGON); para as 
propriedades e leis do processo de coleta e suas decorrências dentro do museu tendo no objeto móvel a fonte autêntica de conhecimento e experiências emocionais (SCHREINEIR, 1989); como teoria das atividades e meios pelos quais a sociedade, com a ajuda de instituições especiais, seleciona, preserva, e utiliza autênticos objetos ilustrando o desenvolvimento da natureza e da sociedade humana (BENES, 1986); como conceitualização e interpretação profissional indicativa de procedimentos válidos para alcançar os objetivos dos serviços de museus (BEDEKAR, 1987); como todo o complexo de teoria e prática envolvendo o cuidado e uso da herança cultural e natural (VAN MENSCH; POUW; SCHOUTEN, 1983); ou conjunto de estratégias especificamente orientadas para esse objetivo (DELOCHE, s.d. $)^{85}$.

$\bigcirc$ ponto de partida centra-se no objeto de museu e na sua relação entre atividades e objetos, e desses para as emoções que eles podem acionar chegando-se, num "mais alto nível de abstração" (VAN MENSCH), à relação, dentro dos museus, entre homem e realidade ${ }^{86}$. $\bigcirc$ autor dessa noção é o tcheco Stránský lapresentado em 1980, no MuWoP/DoTraM como diretor do Departamento de Museologia do Museu da Morávia; Brno; Tchecoslováquia, e também da Faculdade de Filosofia na Jan Evangelista Purkynk Universit, na mesma cidade), sua concepção difundiu-se a partir de um artigo escrito pela tcheca Anna Gregorová ${ }^{87}$.

Entretanto, na análise de van Mensch, essas abordagens estariam mais vinculadas à prática do que à teoria, sem uma distinção ("clara", escreve) entre as funções institucionais do museu e as da Museologia. Para o norte-americano Ellis Burcaw, essa abordagem - que ele situa como "a dos alemães" - era "uma tendência fatal". Eles estavam indo "longe demais"88.

Na Museologia orientada para museus, a perspectiva "mais popular entre os que trabalham em museus ("museum workers"), corresponde a organização da instituição ${ }^{89}$. Posteriormente se expandiv e, além da organização, corresponderia também ao estudo da história dos museus, do seu papel na sociedade, da sua pesquisa específica, da conservação, educação, relacionamento com o meio ambiente físico e classificação de seus diferentes tipos (lcom, 1972), agrupados nos chamados "estudos de museu"90.

Desse núcleo também partiram outras concepções como a de W. Gluzinski (1983), que em sua "Museologia postulada" propôs a "essência [de] museu", o "fator $M$ ", referindo-se à transmissão simbólica de valores impregnados nos objetos, uma questão de comportamento cultural especificamente manifestado nos museus, envolvendo questões de classes sociais, já que a forma do objeto estaria por eles marcada ${ }^{91}$.

Críticas feitas a essa abordagem recaem sobre o fato de que o museu não pode ser objeto de conhecimento, mas só sua base de referência UAHN, 1981 l, seu ponto apriorístico. Nesse aspecto, uma analogia bastante utilizada e divulgada procura demonstrar que Museologia não é a ciência dos museus. Ei-la: da mesma forma que a Pedagogia não é a ciência das escolas, não existe, ângulos de análise múltiplos.

80. De Stránský:"O objeto de conhecimento [que] adquire intenção da museologia é musealidade concebido no contexto de sua história completa e função social presente e futura". Depois ele a relacionou com autenticidade e,posteriormente,com "aspecto específico da realidade" (1980) mudando sua interpretação de Museologia:"A missão da museologia é interpretar cientificamente a atitude do homem com a realidade $[$ i.e. a atitude específica na qual encontra sua expressão de inclinação para adquirir e preservar autênticos valores] que nos faz compreender musealidade no seu contexto histórico e social". Diante dessas alterações van Mensch refere-se ao conceito de musealidade de Stránský como "velho" e "novo" conceito. Klaus Schreiner critica Stránský, dizendo que o conceito de musealidade é produto do "pensamento burguês", e o considera somente como "uma parte da teoria museológica" (VAN MENSCH, Object of knowledge, 1992, 2 e 3 de 11).

81. VAN MENSCH, Object of knowledge, 1992, 3 de 11 .

82. As concepções de Razgon, Deloche, Benes, Bedekar, Jahn, Pouw, Schouten, Lewis e Burcaw, estão apresentadas em van Mensch, 1992, incluindo Shimpff, citado no decorrer do texto mas não na bibliografia. (SHIMPFFT apud van Mensch; 1992: Object of knowledge: 4 de 11).

83. Entre os autores e concepções de Museologia van Mensch cita em primeiro lugar os do Leste europeu; as dele (Pouw e Schouten; 1983); e o francês Deloche. Escreve: "Contrary to the East European approaches (...) 
the activities are not seen as exclusively implemented within the context of the museum institution. In other words: there is also a museology outside museums" (VAN MENS$\mathrm{CH}$; Object of knowledge, 1992, 4 de 11).

84. VAN MENSCH, Object of knowledge, 1992, 4 de 11.

85. Id., 5 de 11

86. Id., 6 e 7 de 11

87. Havia simultaneamente (publicados no $\mathrm{Mu}$ WoP, n. 1,1980) outros colaboradores influenciados por Stránský ou Gregorova: Gluzinski (como "fator M", 1983), Waldisa Rússio (com "fato museal", 1981 e 1983); Spielbauer (com uma museologia "ativa" em dinâmico intercâmbio entre indivíduo/audiência/comunidade; 1988$)$. Ou de outras concepções como as de Edwina Taborsky dentro de uma perspectiva semiótica (museus lidam com a preservação e produção das imagens sociais e delas geram conheci mento; 1982), seguida pela brasileira Maria de Lourdes Horta (1987) (VAN MENSCH. Object of kno wledge, 1992, 4 a 6 de 11).

88.VAN MENSCH. op. cit., 7 de 11

89. Concepção relacionada à definição de Museologia de 1958 , pela Unesco, Rio de Janeiro (cf.VAN MENSCH. op. cit., 2, 7 de $11)$.

90.Visão de um "empirismo estreito", segundo van Mensch (VAN MENSCH, op. cit., 1992, 7 de 11).

91.VAN MENSCH, op, cit. 7 de 11

92. Šla apud VAN MENS $\mathrm{CH}$, op, cit., 7 de 11 .

93.VAN MENSCH, op, cit. 8 de 11 escreve Tomislav Šola, a "escolologia", ou "igrejologia", ou a medicina dos hospitais; o que há são princípios gerais teóricos aplicáveis - para as escolas, os princípios pedagógicos. Igualmente não há, deve-se concluir, uma "ologia dos museus" (museum-ologia) como a ciência de museus, mas sim a Museologia como princípio geral92

Desde Neustupny (anos 1950), o museu não poderia ser um objeto de estudo, pois se apresenta como instrumento condicionado historicamente à integração de várias disciplinas ${ }^{93}$.

Para o norte-americano ${ }^{94}$ Ellis Burcaw, tratava-se de uma questão de intenção do termo que, no entanto, não poderia ser aplicado ao trabalho de museus privados, comerciais ou não-profissionais nem aos museus típicos do passado e aos trabalhos dos do futuro ${ }^{95}$. Para Šola, restringir os museus às atividades, mesmo que dentro do seu campo, e ter uma atitude idêntica com relação ao ambiente e à sociedade, seria repetir as limitações, uma visão estreita ${ }^{96}$.

As concepções são criticadas e, no rebate, os autores apresentam argumentos e contra-argumentos ${ }^{97}$. Vejamos um exemplo mais detalhado desse diálogo entre "museologias" acompanhando a posição de Ellis Burcaw, num documento do ISS (1983) e, em contraponto, poucos anos depois, a do iugoslavo Tomislav Šola, o qual não participa no ISS da discussão sobre ecomuseus, num artigo para a Museum, na seção Tribuna Livre (1987). Ambos compreendiam que a Museologia seria uma ciência independente, mas de ângulos diferentes. Para Burcaw, era o resultado do cruzamento das atividades internas dos museus e nada mais, perspectiva partilhada por alguns europeus. A "museologia-ciência" seria algo para descrever, organizar e prescrever ${ }^{98}$. Para Šola, ela deveria ser mais ação do que instituição, deixando de ser obsoleta na medida em que assimilava o que the era contemporâneo.

Ellis Burcaw, um personagem que aparece no ISS e no MuWoP/DoTraM, não tinha dúvidas sobre a Museologia como ciência, embora afirmasse não ter pensado nela como disciplina teórica e filosófica. Para ele, o termo museologia era necessário, mas algo próprio dos profissionais de museu: "um termo que pertence aos museus contemporâneos da forma como é definido pelas nossas organizações profissionais e como é descrito e promovido pelos periódicos e convenções [dos] museus".

Atribuiu e responsabilizou outros significados para Museologia em razão das diferenças entre regimes políiticos, aplicando para os museus a mesma divisão então em vigor no mundo - países capitalistas de um lado, socialistas do outro - sem se esquecer de declarar a importância da cooperação internacional e da troca de idéias e informações. Para Burcaw, os socialistas (o MuWoP/DoTraM é considerado por ele um jornal dos países socialistas) é que tinham a necessidade de atribuir um nome para "essa nova ciência", recomendando: "Deixe-os escolher um outro nome", mas Museologia, usada no sentido tradicional, criaria menos confusão "para a maior parte do mundo". Para ele, o sentido tradicional a 
vinculava com uma teoria de museu e não com a "realidade material da humanidade", tal como empregado pelos socialistas, uma vez que essa concepção não estava necessariamente em conexão com os museus.

"Deixar" a Museologia como se apresentava era torná-la "mais científica, mais intelectual, mais eficiente, mais sistemática enquanto ainda servia como ciência de museu". $\bigcirc$ esquema proposto de Museologia Geral, Especializada e Aplicada (museografia) acomodava, no seu entender, as necessidades dos museus tanto em relação aos contextos culturais como à profissão internacional.

Burcaw, diante de tais argumentos, defende uma única Museologia Geral, igual em qualquer lugar do mundo e também uma unicidade de profissão. Mas, a mesma unicidade não valeria para os museus, assim, os de "posição comunista" serviam a propósitos marxistas-leninistas, encorajavam o público a aceitar a política e padrões econômicos dos seus governos; esses estavam a serviço da disseminação de uma doutrina. Isso o fez questionar o que de fato seria estar "a serviço da sociedade" 99.

Assim as idéias de Burcaw foram rebatidas, por não ser possível aceitar uma Museologia dividida em Leste e Oeste, pois o comando das decisões sobre os museus não seria da alçada política, mas uma tarefa que deveria estar na mão de curadores ${ }^{100}$; outros, reutilizando a mesma expressão (deixe - let em inglês), sugerem, na contramão das idéias de Burcaw, que ele sim deixasse que fosse proposta uma teoria no sentido de ciência, respondendo: "deixe-nos testar uma teoria com o melhor de nossas habilidades", ou ainda, "deixe-nos ter mais diálogo e avaliação crítica dos nossos respectivos pontos de vista".

Despontam então sugestões para que se refaçam as definições do lcom com o argumento de que a definição de museu já havia mudado no decorrer dos anos, mas a de Museologia "não era tão velha". Um comentador compartilha com Burcaw a idéia de denominar a tal nova ciência não de Museologia, mas "ciência material" ("material science"), ou de "heritologia", seguindo a proposta de Tomislav Šola. Um outro comentador alerta sobre a confusão criada por Burcaw entre "teoria" e "ideologia" ou "filosofia política". Outro ainda retruca que os museus deveriam ser guiados pelo tipo de trabalho com coleções, preservação, exposições, educação, e não por diferenças ideológicas, essas desnecessárias ${ }^{101}$.

A posição de Burcaw não foi um episódio único nem tão completamente desarticulado do que se pensava sobre a necessidade de identificar o ponto no qual a Museologia se fazia disciplina independente. A posição assumida por esse representante norte-americano lo que não se diz da maioria, mas naquele momento era um colaborador presente nos escritos do ISS e MuWoP/DoTraM) provavelmente correspondia a um pragmatismo menos tendente a tornar complexa a relação que the parecia inútil desatar entre Museologia e museu.

Em terras européias, a independência era esperada a "mais de um século", segundo Šola, num texto traduzido do servo-croata. A independência desse conhecimento particular, disciplina acadêmica ou disciplina científica, -
94. Com base em dados numéricos sobre o perfil do Icofom van Mensch afirma que naquele período os norte-americanos estariam menos inclinados a participar deste comitê (VAN MENSCH. International Committee for Museology, 1992, 11 de 20).

95. BURCAW, 1995, p. 14.

96.VAN MENSCH, International Committee for Museology, 1992,8 de 11.

97. Klaus Schreiner critica Stránský que critica Šola e a concepção de "heritologia" com o argumento de que o que cabe ao museu é a "específica relação do homem com a realidade" (em 1984). Hofmann critica o conceito de "objeto de museu"; Schreiner, Ilse Jahn e Benes criticam a distinção de Maroevic para informação cultural e a científica, que teria sido influenciada pelo conceito de musealidade de Stránský (Ver VAN MENS$\mathrm{CH}$, Object of knowledge, 1992, 2-4 de 11). Novamente Burcaw, no contraargumento, declara acreditar que cada teoria tem sua aplicação prática. Na contra-argumentação de Bedekar, a Museologia e museu são "nomes dados [...] para enfatizar dois aspectos de um único empreendimento humano", aqueles que pensam o contrário, diz, fazem "uma tragicomédia da museologia contemporânea". O alvo de Bedekar foi Stránský (VAN MENSCH. Object of knowledge, 1992,8 de 11).

98.VAN MENSCH, 1989 b, 20 ou 21 .

99. BURCAW, ISS, n. 1 , 1995: $13 ; 14 ; 12 ; 14-15$

100. BURCAW. ISS, 1955 , n. 1, p. 57.

101. (aspas do autor) ISS, n. 1, p. 111-112

102. S̆OLA , 1987, p. 47 
103.Para Šola, o museu tradicional era resultado de uma "ambição escatológica”, uma manifestação do "complexo faraônico" da humanidade. Lugar solene,reservado a iniciados sugerido pelas entradas majestosas refletindo sobre os objetos que expõe. Neles, a peça de coleção é antes de tudo um objeto de valor (por seu material, trabalho, raridade), com função de fomentar o prestígio dos colecionadores. Sem "querer abolir o Louvre", para ele, esse tipo de museu seria transformando num "monumento do patrimônio histórico e cultural" (ŠOLA 1987, p. 47).

104. No contexto dos ecomuseus, a primeira geração de museus seria dos parques naturais regionais, a segunda, a do museu da comunidade urbana (área industrial) de Le Creusot Montceau-les-Mines, França (cf. EVRARD, 1980) um museu "aber to",operando na forma de "antenas" com centros de animação, coleta, pesquisa, atividades educativas culturais (EVRARD, 1980, p. 227).Após Le Creusot, seriam os ecomuseus de "terceira geração", "museus da recessão", (HU BERT, 1985, p. 188). Para outra concepção de geração de museus ver PADIL LA, 2001

105. S̆OLA, 1987, p. 47.

106.THIVIERGE, 1985, $\mathrm{p}$ 4-6.

107.(Itálico do autor), S̆OLA, 1987, p. 47 e 49.

108. A função educativa dos museus foi firmada num seminário organizado pela Unesco e o Icom, no Rio de Janeiro, em 1958 (de 7 a 30 de setembro) (cf. ARAÚJO; BRUNO, 1995)

109. O português Mario Canova Moutinho relata em seus comentários sobre a Declaração de Que- expressões muitas vezes empregadas como sinônimos - tinha origem, na sua visão, no estabelecimento de um sistema, "traço distintivo de qualquer ciência", e de uma "terminologia museológica digna desse nome". Para ele lou quantos mais?) era desalentador perceber que embora houvesse esforço por parte de especialistas para tentar formular proposições, no sentido de mostrar as origens da Museologia, elas eram numerosas, complexas e incorretas. Centrá-la nos museus, além de ser um "difícil trabalho de parto"102, demonstrava a situação caótica de uma Museologia sem o caráter de ciência. Era frustrante. Para que ela se tornasse ciência, seu conselho era de que se deveria aceitar em primeiro lugar a obsolescência de concepções e de métodos.

Explicava o que era obsoleto.

A Museologia tradicional, a da "ciência dos museus", não conseguia justificar nem mesmo a existência do museu clássico ${ }^{103}$ presa à lógica do século XIX (o autor não explicita) e aos conhecimentos práticos e centrada na instituição, dessa forma redutiva, afirma. Também não dava conta de justificar nem a "segunda geração de museus" 104 . Mesmo considerando a Museologia "inexistente" 105 , Šola procura, com sua crítica, encontrar lugar e justificativas para falar de Museologias, no plural, o que estava ao mesmo tempo correto e incorreto. Vai aos argumentos: correto se pensarmos que ciência é universal, uma e única; incorreto, pois a Museologia tradicional "é [...] ineficaz e incapaz de ser aplicada fora do contexto cultural que the deu origem".

O que Šola procurava defender são os caminhos que chamou de alternativos, impossíveis, àquela altura, de serem suprimidos. Referia-se aos ecomuseus (ecomuseologia), experiência irradiada da França, como um quadro que podia ser ainda mais ampliado por outras expressões: museologia comunitária ou popular, museologia ativa ou experimental, museologia antropológica ${ }^{106}$. Era tão forte essa presença alternativa que o próprio lcom tinha sido levado a reconsiderar (desde o período de sua criação, afirma) suas funções, objetivos e métodos. Uma vez que "tudo" poderia ser considerado peça de museu, agora eram as idéias e não mais os objetos (ou coleções; a esfera física, material) o foco da Museologia, pois, conclui, sua esfera "é de caráter metafísico". Categórico, diz: "O verdadeiro objeto de museu é a transmissão de informação pertinente, cuja forma de apresentação não é necessária e exclusivamente o objeto tridimensional." Informação e comunicação passam a freqüentar os discursos sobre museus.

As conseqüências dessas mudanças, pensava Šola, eram "imprevisiveis", o museu poderia pertencer até mesmo ao passado ${ }^{107}$.

Nova Museologia

Não havia dúvidas sobre a função de preservação e educação lou função pedagógica) ${ }^{108}$ desempenhada pelos museus para a sociedade e 
compreendida como sua verdadeira missão. Outros, no entanto, se não desconsideravam a importância dessas funções, questionavam a posição dos museus estratificada numa hierarquia "de cima para baixo" ou da instituição para o público. A inquietude vinha da constatação de que essa hierarquia não correspondia de fato às necessidades da sociedade, especificamente de determinados grupos sociais mais vulneráveis às mudanças econômicas e políticas.

Nesse contexto, os museus e os seus objetos seriam o limite do patrimônio? Contrapunha-se então, no plano das concepções, a ação do museu tradicional (sintetizado na conservação/preservação, edificação, objeto e públicol e as possibilidades de ação considerando-se os problemas da sociedade. A inquietação levou ao descontentamento, e o lcofom chegou ao ano de 1984 com uma questão interna para resolver: a de integrar ou não os movimentos novos que reivindicavam seu lugar e fala ${ }^{109}$. A Museologia tradicional se encontrou, e se defrontou, com a Nova Museologia ${ }^{110}$.

Os adeptos dessa filosofia de ação preconizavam uma "museologia popular" 111 , cujo aspecto significativo seria compreender e empregar as atividades de preservação do patrimônio - o zelo pela Cultura - como operadoras concretas de transformações, auxiliando inclusive a revitalização de postos de trabalho e retomando artesanias, atividades agrícolas e industriais ${ }^{112}$.

Há evidentemente nessas propostas aspectos políticos e econômicos explícitos. Atravessava-se, dos anos 1970 para os 1980, uma das fases de recessão econômica mundial. Essa ação, na análise do francês Marcel Evrard, seria um projeto experimental, um instrumento de "compreensão e [...] matriz de mudanças econômicas, sociais e culturais" ${ }^{\prime 13}$.

Para Pierre Mayrand, elas instalavam transformações radicais nas finalidades da Museologia e, em conseqüência, na mutação da mentalidade e atitudes dos "museólogos". Tais mudanças não vieram repentinamente e chegaram ao lcofom (em Londres, 1983) na forma de descontentamento dos participantes com reclamos de que as resoluções emitidas na Mesa-redonda de Santiago do Chile (lcom, 1972) não eram seguidas. Principalmente a ala jovem dos museólogos estava insatisfeita com o monolitismo das instituições e a marginalização das experiências que estavam ocorrendo ${ }^{114}$. Segundo Huges de Varine-Bohan, nesse encontro da América Latina ficou estabelecida a função do museu como instrumento de desenvolvimento, gerando efeitos sobre sua função social e sobre os museólogos chamados à responsabilidade política. Mais do que especializações disciplinares, importavam as questões de identidade e de territórios de populações, momento no qual proliferam as "museologias nacionais 'incultas' "115.

Um grande pólo difusor das novas idéias foram as experiências desenvolvidas na França, qualificadas de profundas por Varine-Bohan, marcando museus, transformando a disciplina e realizando uma revolução radical ${ }^{116}$. Ele, o homem que inventou o vocábulo "ecomuseu"117, considerou que, embora bec, 1984, no Ateliê Internacional Ecomuseus Nova Museologia, a tentativa ocorrida para intercambiar experiências da ecomuseologia e da nova museologia e também de relacioná-las com a Museologia em geral. Nesse encontro, um grupo de museólogos desiludidos com a "atitude desagregadora do Icom e em particular do Icofom [..] claramente manifestada na reunião de Londres de 1983, rejeitando liminarmente a própria existência de práticas museológicas não conformes ao quadro estrito da museologia instituída" reuniu-se de "forma autônoma" para avaliar, conceitualizar e dar forma a uma outra organização e Museologia alternativa, que se opunha a Museologia de coleções a favor de uma de caráter social. Foi criado o Movimento Internacional para uma Nova Museologia (Minon) que contribuiu para o "reconhecimento no seio da Museologia, do direito à diferença" (ARAÚJO; BRUNO, 1995, p. 26 e 29).

110. André Desvallées diferencia o período do conceito de Nova Museologia e sua oficialização, que teria ocorrido em 1982, numa assembléia da Associação dos conservadores franceses quando Évelyne Lehalle com Chantal Lombard,Alain Nicolas e Willian Saadé, estabelecem os estatutos de uma associação a Museologia nouvellle et expérimentation sociale (MNES). Numa retrospectiva possível das diferentes fontes das quais poderia ter nascido (ou influenciado) o conceito de Nova Museologia, aponta: 1957 - Freenam Tilden lança a visão de interpretação do patrimônio que teria revolucionado a museografia dos centros de interpretação; 1962 George Henri Rivière, presidente do Icom desde 1946, e Huge de Varine, como criadores do ecomu- 
seu; 1966 - os primeiros museus in situ de parques naturais. Ou também na reunião em Aspen (Colorado) em que Sidney Dillon Ripley, secretário do Smithsonian Institution, lança a idéia de um museu de vizinhança experimental e dá a Kinard a possibilidade de desenvolver seu projeto em Anacóstia. 1969 - o seminário ocorrido no Bedford Lincoln Neighborhood Museum (Brooklyn; EUA) sobre "museus de vizinhança" (neigbborbood museum) e o "papel do museu na coletividade" do qual participou Emily Dennis-Harvey e John Kinard fundador do Neighbordhood Museum no bairro de Anacostia em Washington. 1971 - entre Paris, Dijon e Grenoble, quando ocorre uma conferência geral do Icom com o tema "O museu a serviço dos homens, hoje e no futuro?" Em Dijon, pela primeira vez, Robert Puoujade primeiro-minis tro lança na França o termo ecomuseu. Em Grenoble, Ducan F. Cameron fala da "linguagem de comunicação nos museus", John Kinard expõe idéias sobre o museu comunitá rio em Washington; Stanis las Adotevi, do Dahomey, fala do elitismo nos museus do Terceiro e Quarto Mundos, nos quais a população não entrava. 1972 com a mesa-redonda realizada em Santiago do Chile, organizada pela Unesco com o tema "Papel dos museus na América Latina", ou com um colóquio realizado em França nesse mesmo ano com otem "Museu e meio ambiente".1978 - "mais conscientemente" usa-se pela primeira vez a expressão "nova museologia” (DESVALLÉES, 1992,15a 19).

111. MAYRAND, 1985, p 200

112. MOUTINHO p. 27 apud ARAÚJO; BRUNO, 1995.
George Henri Rivière tenha procurado dar forma e significação à palavra ${ }^{118}$, sua aplicabilidade variava de um lugar para o outro - "de centro de interpretação a instrumento de desenvolvimento, de casa do parque a museu artesanal, de conservatório de etnologia a centro de cultura industrial" ${ }^{119}$ - e no modo de adaptar essa filosofia de transformação a diferentes condições locais. Tanto Varine-Bohan como Rivière tinham fortes laços com posições políticas em seu tempo ${ }^{120}$.

O cerne dessa concepção de museu localizava-se numa noção ampla de patrimônio, dito "patrimônio total", e compreendia, conforme Mathilde Bellaigue, "as paisagens, sítios, edificações, bem como os objetos que são portadores de história ou de memória"121. Essa proposição casa-se com a proposta de que os museus se dessacralizassem, se socializassem e se envolvessem com populações ou comunidades ${ }^{122}$, guiados pela aproximação com elementos do patrimônio, ampliando a noção desse e do que poderia ser um acervo le não os preterindo) ${ }^{123}$. A inserção da comunidade no processo seria de tal monta que todos poderiam se tornar "conservadores de museu"124.

Um "instrumento para o desenvolvimento", valorativo de um conjunto de fatores potenciais de um território laspectos físicos, culturais, humanos e econômicos) $\left.\right|^{125}$, dava ensejo, dependendo de condições locais, como zonas em degradação, a políticas de aproveitamento, incentivadoras, em alguns casos, do turismo em regiões empobrecidas ${ }^{126}$. A idéia de museu, um meio, um bom meio, poderia então auxiliar num processo de retomada, mobilizando todo um grupo de um dado território, mais técnicos, especialistas, pesquisadores e as instâncias administrativas do Estado, uma outra forma de estatuto associativo (no caso dos ecomuseus, na Françal) ${ }^{127}$.

Os museus tornavam-se, ou poderiam se tornar, generalizando-se a experiência do primeiro museu em área industrial, a do Creusot Montceau-LesMines (França), adjuntos de militância política e meios para a autogestão de uma comunidade ${ }^{128}$

Uma linha de ação de museus foi descrita por André Desvallées como um movimento de pensamento, de resistência, uma escola de contestação ${ }^{129}$, e para François Hubert como uma intensa efervescência cultural e ideológica ${ }^{130}$. Para Heloisa Barbuy, um traço de permanência, já que estava atrelado às raízes da cultura francesa com longa tradição museológica, decorrente de um processo de maturação surgido no século XIX, que envolvia o interesse pela chamada cultura popular ${ }^{131}$. Essa forma de museu, explica Hubert, tinha nascido em tempos de prosperidade ${ }^{132}$ (pensando-se desenvolvimento, ecologia e questões regionais), tornando-se, pela pressão econômica, "museus da recessão". Havia diferenças entre os ecomuseus: alguns poderiam ser denominados "ecomuseus comunitários", movidos pela filosofia de autogestão e autodesenvolvimento, opondo-se aos "ecomuseus institucionais" (tutelados administrativamente) mais sujeitos à manipulações políticas do que os primeiros ${ }^{133}$. Tais ações não estavam isentas de riscos, como o reforço de dogmatismos, pois tocavam diretamente a noção 
de identidade cultural ${ }^{134}$, marcando um nódulo central e problemático dos ecomuseus situados entre o caráter revolucionário e conservador para a construção das identidades culturais, segundo as palavras de Heloisa Barbuy ${ }^{135}$. Ocorreram dificuldades para equilibrar a teoria emanada dessas experiências e a prática ${ }^{136}$ e até mesmo certo romantismo nas formas de interagir (ou idealizar) com as comunidades, de acordo com a autora ${ }^{137}$.

Essa era uma experiência nada tradicional para os padrões europeus e que se encaixava com facilidade em continentes como a América Latina e a África, com menores recursos e nos quais as populações se encontravam bastante distanciadas dos museus. Todavia, por meio da implantação dessas ações inovadoras (ou similares), tais populações poderiam encontrar nos museus um outro e novo apoio ${ }^{138}$. Tais propostas, num avesso da Museologia dita oficial embasada nos museus e suas coleções, foram captando seus defensores e propagadores. Estar-se-ia num outro momento, num outro tempo em que, como advogava Waldisa Rússio, os museus deveriam ser reconhecidos pelas comunidades, seria mesmo um resultado delas, de seu empenho e de sua participação. Invertiam-se, assim, os papéis: os museus não deveriam ser feitos para a comunidade, mas com ela ${ }^{139}$. Essas propostas se reproduziram em várias partes do mundo com a denominação "ecomuseu"140 - então a "forma mais avançada da museologia contemporânea"141.

No lcofom o tema "Museus, território, sociedade: novas práticas, novas tendências" foi abordado em 1983 (Londres), na mesma reunião em que foi discutida a metodologia da Museologia e seus aspectos profissionais ${ }^{142}$. Vinos Sofka, seguindo seu método de trabalho, propôs tópicos relacionando aspectos teóricos, referentes à ecologia e ao ecomuseu, e práticos para debater as atividades desse museu, incluindo projeções para o futuro ${ }^{143}$. No MuWoP/ DoTraM, George Henri Rivière ao explicar a dinâmica da interdisciplinaridade, na instituição museu, apresenta os ecomuseus como "um novo sistema cultural e social"144.

Para Peter van Mensch, o emprego do termo "nova museologia" conecta-se com as mudanças de papel dos museus no que diz respeito à educação e à sociedade como um todo e foi monopolizado por duas organizações: a Association Muséologie Nouvelle et Experimentation Sociale (MNES), fundada em 1982 na França, e o Mouvement Internationale pour la Muséologie Nouvelle (Minon), criado em 1985, por um "grupo de pessoas não satisfeitas com a política do lcofom"145.

Fato é que essa movimentação e as expectativas de mudança acabaram acarretando, no âmbito institucional do lcom, uma seqüência de conceitos expressos em documentos oficiais: o de "museu integral"146, destinado a proporcionar à comunidade uma visão de conjunto do seu meio material e cultural (Chile, 1972) 147; o de Nova(s) Museologia(s), "ecomuseologia, museologia comunitária e todas as outras formas de museologia ativa", como modo de gestão importante para o desenvolvimento das comunidades (Declaração de Quebéc, 1984)148, e alguns anos mais tarde, o de "museu
113. (Aspas do autor) Marcel Evrard reapresenta o museu "eclaté" da comunidade urbana de Le Creusot Monteceau-les-Mines, na França (EVRARD, 1980, p. 227,199$)$.

114. MAYRAND, 1985, p. 199-200.

115. (Aspas do autor) VARINE, 1995, p. 19.

116.VARINE, 1985, p. 17.

117. Segundo François Hubert, a primeira experiência do Le Creusot Montceau-les-Mines, em 1974 , recebeu o nome de ecomuseu, sendo o prefixo "eco" usado para designar a importância que se deu ao meio natural e social. Esse autor aponta como preocupação essencial de Rivière de um lado a ecologia e a etnologia regional, de outro a participação e autogestão, para criar um novo tipo de museu. Isso levaria a um novo "sistema museográfico" associando ateliês, documentação, "magasin" de objetos, e assim por diante - as conhecidas "antenas" ou "comunidades associadas" (HUBERT, 1985, p. 187)

118. Huges de Varine-Bohan refere-se a Définition évolutive de l'écomusée, cunhada por George Henri Rivière, que passou por várias versões (a última de 1980). Em síntese e grosso modo, ela circunda a noção de ecomuseu em instrumento, espelho, expressão do homem e natureza, expressão do tempo e do espaço, um laboratório, um conservatório, uma escola. O encaixe mais significativo é a inserção da população de um dado território para conhecê-lo em profundidade (sua história e as gerações que os precederam, os aspectos geográficos, etc.) obtendo elementos de análise e crítica que os fizesse compreender e interferir no seu futuro (RIVIÉRE, 
1985, p. 182-183). Fran çois Hubert explica que da inter-relação da Ecologia e Etnologia regional, uma concepção de siste ma museográfico organizado e um comitê formado por usuários, gestores e pesquisadores, ter-se-ia a "escola mútua" tendo como meta o desenvolvimento da comunidade. $\mathrm{O}$ sistema museógrafico associaria itinerários ta qual antenas (HUBERT, 1985, p. 187)

119.VARINE, 1995, p. 17.

120.Varine-Bohan fundou uma ONG internacional (Instituto Ecumênico para o Desenvolvimento dos Povos) em 1972, tendo confiado ao brasileiro Paulo Freire a presidência desse organismo (VARINE, 1995,p. 17). Rivière foi ligado ao Front Popula (partido socialista fran cês), (BARBUY, 1995, p 211 e 215).

121. BELLAIGUE apud BARBUY, 1995, p. 211.

122. BARBUY, 1995, p 209.

123. H. Barbuy explica que houve uma tendência "antipatrimonialista", mas contra o excesso de espírito classificatório herdado, na França e outros países da Europa (Itália,Alemanha, Áustria, e outros) dos naturalistas. A noção de acervo que muitos erroneamente pensam abolida nos projetos de ecomuseus é ampliada, pois os conceituadores dos ecomuseus se centraram justamente num sentido específico de patrimônio que viam neles informação, carga afetiva e simbólica. A pesquisa em torno desses bens seria um outro traço diferencial e forte dos projetos de Rivière (BARBUY, 1995, p. 210211).

124. EVRARD, 1980 p. 227 . integrado" da Declaração de Caracas (1992), "termo não formulado, mas implícito nas propostas e postulados do Documento", que propôs ações e processos contemplando particularidades de contextos específicos, de acordo com Maria de Lourdes Parreiras Horta ${ }^{149}$.

As idéias dessa "ala" da Museologia foram sendo incorporadas e empregadas na área, acrescentando conceitos novos à sua linguagem de especialidade. Na prática, essas experiências se espraiaram muito pelo desejo de que os museus agissem de forma mais socializante. Paralelamente a essas novas experiências, procurou-se articular no comitê o sistema da Museologia: a organização sistêmica - do que lhe seria orgânico, pode-se dizer - pensandose o campo do conhecimento em interação consigo e com disciplinas próximas.

Entre teoria e prática segundo o lcofom

Compatibilizar teoria e prática para os colaboradores do Icofom demandou reflexões - e também tato e diplomacia ${ }^{150}$ - sobre o que viria a ser a estrutura interna da Museologia como disciplina, o que fez os colaboradores se voltarem para a relação entre a teoria da Museologia e a prática exercida pelos museus; uma estruturação da disciplina com disciplinas "vizinhas" e em seu próprio terreno, o que se denominou "domínios conexos". Essa Museologia in statu nascendi era estudo para alguns anos, segundo Jan Jelinek ${ }^{151}$, que considerou relevante essa discussão dentro do comitê pelos seguintes aspectos: a) configurar a estrutura e o campo teórico da Museologia, b) para os cursos em universidades e c) prover uma dada organização para as estruturas dos museus ${ }^{152}$.

Essas demarcações, por sua vez, levaram esses colaboradores a duas instâncias de relações consideradas estruturais, envolvendo os comitês do próprio Icom, que refletiam a área, pelas especializações que tratavam ${ }^{153}$, e os programas de cursos de formação ou treinamento. Dessa forma ter-se-ia a composição dentro da sistemática da Museologia e da museografia, atendendo também aos programas de formação para fortalecer o aprendizado formal, uma vez que havia muitos que trabalhavam em museus guiados somente pela experiência prática $^{154}$, ainda segundo Jelinek.

Paralelamente aos aspectos formativos havia a faceta propriamente científica. Para fundamentá-la, Z. Z. Stránský buscou inspiração na Teoria Geral dos Sistemas (concebida pelo biólogo Ludwing von Bertalanffy)155, procurando demonstrar as vantagens dessa aplicação - um modelo teórico então contemporâneo da moderna ciência - aos museus. Os resultados apontavam, no sev entender, o traçado da Museologia como ciência especial e independente, possibilitando observar os museus em relação com o meio lpara Stránský, o 
museu e suas realidades) e não mais isolados em si mesmos, ou seja, a "realidade do museu como um todo"156.

Empregar esse modelo serviria como prova de verificação do estágio em que a ciência-museologia se encontrava, na medida em que se fazia um paralelo entre o processo de desenvolvimento da ciência em geral e o desta em particular ${ }^{157}$. $\bigcirc$ argumento foi o de que a Museologia não poderia estancar no nível empírico-descritivo em que se encontrava, o qual não seria a "típica feição da museologia". Importava situar as "esferas adjuntas" do sistema e, eventualmente, da própria Museologia. Analisando-se os museus sob essa perspectiva, poder-se-ia aferir e, assim, esclarecer o impacto de determinadas combinações, como a relação entre museu e Pedagogia le em museu, a Pedagogia de museu), Sociologia (particularmente a Sociopsicologia na avaliação das técnicas de apresentação, portanto, das exposições), Teoria da Comunicação e Informática - o impacto mais radical no pensamento museológico - no entender de Stránský. $\bigcirc$ ponto aqui era identificar alguns problemas de intersecção, de tal modo que a Museologia alcançasse o nível teórico para tornar-se companheira de outras disciplinas científicas, chegando assim a uma real integração e bilateralidade de elos ${ }^{158}$.

É no emprego da informática nos museus que Stránský situa (mas não explicita) os problemas de terminologia. Pode-se inferir que eles tenham surgido em razão da necessidade de padronização e normalização da linguagem visando ao registro à indexação das denominações e descrições sobre os objetos e coleções, tendo em vista a implantação de sistemas informatizados para a documentação de museus.

Os colaboradores se submeteram a um exercício para organizar o conhecimento museológico em "modelos", expressão usada por van Mensch"159. Uma divisão ou modelo consagrado separava em duas categorias básicas esse conhecimento: Museologia geral correspondendo a teoria (no plano geral) e Museologia prática ou museografia (prática de museu ou trabalhos com a exposição ou ainda montagem de exposições). Desse modelo derivam subdivisões na dependência do encaixe daquilo que, partindo de certa visão do objeto de conhecimento, ou da área como conjunto articulado, poderia ser tomado como teoria ou prática.

Um outro modelo se baseava numa divisão tripartida: Museologia geral (a teoria na qual a prática de museus se apoiava), Museologia especial las teorias particulares desenvolvidas para a aplicação de diferentes disciplinas dentro do contexto do museu) e Museologia aplicada (a aplicação dessas teorias na prática dos museus, a museografia) ${ }^{160}$. Um outro desdobramento propôs quatro módulos: Sociomuseologia (ou Museologia social), histórica, teorética e aplicada (de Stránský). Um outro cinco módulos: Museologia geral, teorética (subdivida por Stránský em três esferas heurísticas: seleção, tesaurização, comunicação|'161, aplicada, especial e histórica.
125. WALLE apud BARBUY, p. 221.

126. BARBUY, p. 215.

127.HUBERT, 1985 ,p. 187.

128. Sobre a experiência do Le Creusot MontceauLes-Mines, cf. EVRARD, 1980, p. 226-234.

129. DESVALLÉES, 1992, p. 15-39.

130. A crise econômica fez nascer, depois da fase de prosperidade econômica, numerosos "pequenos ecomuseus" (HUBERT, 1985, p. 187).

131. H. Barbuy identifica o interesse pela cultura popular em várias expressões da cultura francesa. A autora exemplifica: na Exposição Universal de 1889, extremamente didática, apresentava-se mostras retrospectivas sobre o trabalho com a reconstituição do interior de uma casa camponesa ou de uma oficina.A tipificação de culturas e tipos regionais foi usada, explica a autora, nessa exposição com a intenção de que o visitante se identificasse com seu ofício e seus costumes. Realizando uma síntese por "imagens-signos", a intenção era de ensinar "pelo aspecto" conceitos ou definições de cultura (aspas da autora). Durante a exposição é realizado o I Congresso Internacional de Tradições Populares, ocasião em que é apresentado por Armand Landrin um projeto de museus das províncias (de artes e tradições populares) para a França, propostos como centros de estudos, vistos assim como museu científico (cf. DIAS apud BARBUY, 1995,p. 213-214). Os museus de etnografia regionais e os de cultura local (museus de folclore) vinham como um contraponto aos museus de belas-artes, ou os enciclopédicos de história (guiados pelos fatos oficiais), os de 
história natural e os de antropologia na esteira en tão dos interesses imperialistas (BARBUY, 1995 p. 212-213, 215)

132. Os ecomuseus foram uma adaptação, realizada por G. H. Rivière, dos museus a céu aberto (ou museus ao ar livre) escandinavos (o primeiro em Sansken, Suécia, meados do século XIX, com a construção de casas de regiões desse país num par que) (BARBUY, 1995; HUBERT, 1985). Em 1967, a criação de parques na turais regionais (na Franca) proporcionou ocasião para que ele propusesse a adaptação (HUBERT, op.cit., 1985).

133. Aspas do autor (HUBERT, 1985, p. 188).

134. MENESES apud BARBUY, 1995, p. 223.

135. BARBUY, 1995,p. 222

136. HUBERT, 1985.

137.BARBUY,1995,p. 210

138. Ver as resoluções comentários sobre as Resoluções da Mesa-redonda de Santiago do Chile (1972); Declaração de Quebec (1984); e na década de 90, a Declaração de Caracas (1992) (ARAÚJO; BRUNO, 1995).

139. Itálico da autora (RÚSSIO, 1984, p.60)

140.cf. Museum, n. 148 v. XXXVII, n. 4 - Images de l'écomusée. Nesse número encontra-se algumas experiências no Ca nadá, Suécia, Portugal, continente africano e América Latina incluindo o Brasil.

141. RÚSSIO, 1983, p. 60.

142. cf. ISS, n. 2 ; reedição de 1995 .

143. Para a Ecologia, na parte teórica, apresentação de seus objetivos, objeto de estudo, sistema e
Tais organizações ou sistematizações da área se prestam inclusive à classificação de acervo de bibliotecas, caso, por exemplo, da biblioteca Reinwardt Academie (Holanda), onde são empregadas desde 1982 como "divisão metodológica-didática" para um "consistente campo de conhecimento", a estrutura científica da Museologia' ${ }^{162}$.

Comentários

Os primeiros tempos do Icofom espelham a pluralidade de concepções que foram surgindo e, ao mesmo tempo, os efeitos decorrentes do emprego polissêmico de determinadas palavras.

engendramento provocado pela questão da Museologia como ciência ainda é questão discutível. Em recente artigo, Peter van Mensch (2000) escreve sobre a falta de consenso que ainda existe do conceito de Museologia como ciência, da ausência de teoria e metodologia própria e do aceite disso por parte daqueles que trabalham em museus. Ele escreve, que embora o tempo tenha passado "temos que admitir que a batalha ainda não está decidida". Afirma que a questão da Museologia como ciência e do trabalho em museu como profissão não está resolvida, sendo que as respostas dependem da perspectiva assumida ${ }^{163}$

Se o caminho, a princípio, foi a coleta de opiniões suscitada por uma série de perguntas e respostas previamente direcionadas, acompanhadas a seguir de um esforço para sistematizá-las e organizá-las num corpo de idéias mais coeso, um dos flancos abertos nesse processo foi o da terminologia da área.

Nesse período, o "problema da terminologia", um "dilema" tal como era considerado pelos participantes do núcleo inicial do Icofom, apresentava-se lado a lado com as tentativas para determinar as margens teóricas e disciplinares da Museologia. $O$ começo desse processo resvalou de início com dificuldades no uso das palavras, fato a se notar quando se tem em mente perscrutar a área da perspectiva conceitual e terminológica uma vez que, para o funcionamento de todas as ciências, as designações e relações formais entre conceitos e termos são vitais ${ }^{164}$

O emprego das palavras é visto como "problema de vocabulário" e empecilho para o desenvolvimento de trabalhos na área de Museologia. $\bigcirc$ ponto recai sobre seu significado que muda de um texto para outro. Essa declaração foi registrada no prefácio de um trabalho publicado por alunos da École du Louvre. São eles que comentam que as idéias sobre Museologia estão localizadas em "determinadas pessoas" e em "determinados países", dificultando a percepção de uma orientação geral. Acrescente-se a necessária tradução, pois os autores das publicações estão "espalhados pelo mundo"165. 
A questão ou problema da terminologia não escapa dos colaboradores do lcofom e é apontada em vários trechos de suas publicações.

Para Peter van Mensch, um dos membros atuantes desse comitê, a terminologia seria uma "linguagem das coisas", uma "terminologia da percepção com significado autêntico e comprovável, expurgado, tanto quanto possível, de julgamentos subjetivos individuais"; algo ainda a ser desenvolvido ${ }^{160}$. Corria o ano de 1983 e, no ano anterior, Vinos Sofka declara num encontro em Paris a necessidade de promover uma "base conceitual comum" para o debate terminológico ${ }^{167}$.

A procura por teorizar a Museologia foi um procedimento intencional com pretensões de, por essa via, torná-la científica na forma de disciplina acadêmica, conhecimento científico e/ou domínio de saber (tal com surge no decorrer de textos das publicações do comitê). Considerada afirmativamente como ciência por seus membros ainda que, no movimento de trazê-la conformada, eles se dessem conta de que não havia um único objeto de estudo.

Percebe-se que houve uma acomodação aparente sob a palavra museologia que, afinal, não escondia um sentido imanente, pois existiam relações a serem esclarecidas e outras a serem estabelecidas. A procurada essência não era espontânea; ao contrário, surgiria de uma construção. Naquele momento de ebulição inicial, a polêmica formada apontava para um vínculo indiscutível entre a necessidade de conceituar e ordenar o que se pretendia como campo específico de conhecimento. Isso porque a conceituação ${ }^{168}$ é fundamental para que áreas especializadas da experiência humana identifiquem seu universo nocional a partir de um dado ponto de vista, a fim de que seja organizado de forma sistemática ${ }^{169}$.

Houve, contudo, um esforço para isolar a área, por mais complexo que tenha sido esse processo. Tal esforço passou pela necessidade de identificar uma determinada linguagem para "falar" Museologia, pois essa é a condição primeira para a expressão de idéias. Relembremos a importância da linguagem, segundo G. G. Granger, como condicionante de todo conhecimento objetivo e determinante dos limites de sua formulação ${ }^{170}$. Tanto é que a ausência de significados precisos incomodava os participantes, pois a Museologia não poderia existir - já era um atestado -, "sem uma terminologia específica" que permitisse "exprimir sua própria essência"171.

\section{REFERÊNCIAS}

ARAÚJO, M. M.; BRUNO, M. C. O. A memória do pensamento museológico contemporâneo. Documentos e depoimentos. São Paulo. Comitê Brasileiro do Icom/FFLCH/USP, 1995.

BAGAHALI, S.A.; BOYLAN, P.; HERREMAN, Y. History of Icom (1946-1996). Paris: International Council of Museums, 1998.

Annals of Museu Paulista.v. 12. Jan.-Dec. 2004. relação com outros ramos científicos, os resultados da disseminação desses para o púbico e o papel do museu nessa concepção. Para os ecomuseus: os fundamentos históricos, objetivos e tarefas, lugar e relações dentro do escopo da tipologia de museus (cf. ISS, n. 2, 1995 - Guidelines for the organization of the symposium, p. 4-5).

144. RIVIÈRE, The dynamics of the role of interdisciplinarity in the museum instituition. $\mathbf{M u}$ WoP/DoTraM, n. 2, p. 5455.

145. VAN MENSCH.Purpose of understanding, 1992, 4 de 7 .

146. Maria de Lourdes P. Horta diz que que veio revolucionar o conceito de museu como instituição e que ainda deixava perceber uma "visão de dentro para fora, e uma 'função social' do Museu com laivos didáticos ou 'catequéticos" (aspas da autora) (HORTA, 1995, p. 32).

147. ARAÚJO; BRUNO, pp. 20-24.

148. Ver Museum, n. 148 v. XXXVII, n. 4, p. 201; ARAÚJO; BRUNO: 1995

149. HORTA, 1995, p. 35.

150. LEWIS. n. 2, p. 74.

151. JELINEK, 1981, p. 69

152. VAN MENSCH. The structure of museology, 1992, 1 de 7.

153. Segundo Jelinek, nos anos 1980 havia somente um comitê internacional de Arte. Os museus de Arte seriam em maior quantidade no mundo (JELINEK, MuWoP/DoTraM, n. 2, p. 69).

154 (JELINEK, 1981, p. 69). O tema "Sistemática e sistemas na museologia" foi tratado no encontro anual do Icofom, ocorri- 
do durante a $12^{\mathrm{a}}$ Conferência Geral e $13^{\mathrm{a}}$ Assembléia Geral do Icom no México, em 1980, tópico que coube a Jelinek (SOFKA, $M u$ WoP/DoTraM, n. 2, p. 67-68).

155.A teoria geral dos sistemas, um sistema de ciência, concebe sistema como um arranjo inter-relacionado e não estático de elementos, propõe a análise de suas propriedades e relações de forma organizada, estruturada e hierarquizada, explicando o comportamento (ou funcionamento) de um dado sistema, cujos resultados seriam ou iriam além desse agregado ( STRÁNSKÝThe theory of systems and museology, MuWoP/DoTraM, n. 2, p. 70-73). Stránský, citando outro autor SADOVSKY, refere-se à penetração dos métodos matemáticos e lógicos nas ciências naturais e sociais. Lembre-se que nos anos 80 , a análise de sistemas tecnológicos estava em voga. Fala-se em sistemas abertos e fechados e, por essa teoria, têmse a máxima: a soma das partes de um sistema é maior do que os elementos que contêm gerando o efeito sinergético.

156. Documento elaborado para o encontro no México (1980). Stránský cita o uso da perspectiva sistêmica em museus em as pectos organizacionais, na informática, arquitetura, nas exposições e desta perspectiva para a teoria da comunicação, estética e semântica (STRÁNSKÝ. The theory of systems and museology, $\mathrm{MuWoP} /$ DoTraM, n. 2, p. 70-71)

157. No primeiro estágio, a Museologia como teoria seria uma ferramenta metodológica para nos ensinar "como fazer um museu"; trata-se do estágio empírico descritivo da teoria e, nesse nivel, seria menos ciência, mas métodos e técnicas das práticas de museu. O segundo
BARBUY, H. A conformação dos ecomuseus: elementos para compreensão e análise. Anais do Museu Paulista, São Paulo, v. 3, p. 209-236, jan./dez. 1995.

BELLAIGUE, M. 22 ans de réflexion muséologique à travers le monde. Cabiers d'études/Study Series. Comité International de lCOM pour la museologie. 8: p. 4-5, 2000.

BOYLAN, P. J. Cincuenta años del Icom. Museum International, 191, 48 (3), p. 47-50, 1996.

CINTRA,A. M. M.;TÁLAMO, M. F. G.; LARA, M. L. G.; KOBASHI, N.Y. Para entender as linguagens documentárias. São Paulo: Polis, 1994.

DESVALLÉES,A. Présentation. In: Vagues: une antbologie de la nouvelle muséologie. Paris: Édition W.M.N.E.S., 1992, p. 15-39.

Pour une terminologie muséologique de base. Cabiers d'étude/Study Series, Comité International de Icom pour la museologie, n. 8, p. 8-9, 2000.

ÉRI, I. Le Dictionarium museologicum: construire des ponts avec des mots. Museum, XXXV(2), p. 110-113, 1986.

EVRARD, M. Le Creusot-Montceau-les-Mines: la vie d'un écomusée bilan d'une décennie.Museum, v. XXXII, n. 4, 1980.

FATTHOUH, N.; SIMENON, N. Icofom - Orientations museologiques et origines geographiques des auteures. Paris: École du Louvre, 1997.

GREGOROVA, A. MuWoP,p.19-21, 1981.

HARVEY, D. Condição pós-moderna. São Paulo: Ed. Loyola, 1989

HÉRNANDEZ, F. H. Manual de museología. Espanha: Editorial Síntesis, 1998.

HOBSBAWN, E. Era dos extremos. O breve século XX. 1914-1991. São Paulo: Companhia das Letras, 2000.

HORTA, M. L. P. 20 anos depois de Santiago: a Declaração de Caracas - 1992. In: ARAÚJO, M. M.; BRUNO, M. C. O. A memória do pensamento museológico contemporâneo. Documentos e depoimentos. São Paulo: Comitê Brasileiro do Icom/FFLCH/USP, 1995. p. 32-35.

HUBERT, F. Les écomusées en France: contradictions et déviations. Museum. 148, XXXVII (4): p. 186-190, 1985.

ICOFOM STUDY SERIES - ISS, Icofom, v. 1-29, 1995 (reimpressão).

INTERDISCIPLINARITY IN MUSEOLOGY. Museological Working Papers (MuWop). Estocolmo: Icofom/Statens Historiska Museum, n. 2, 1981.

JENSEN, Museological points of view - Europe 1975.MuWop, n. 1, p. 6-10, 1981. 
LEWIS.The systematics of museology, its application to Ilom's International Committees an the nole of Icoom. MuWop/Dotra $M, \mathrm{n}^{\circ} 2, \mathrm{p} .74$.

MAYRAND, P. La nouvelle muséologie affirmée.Museum, 148, XXXVII(4), p. 99-200, 1985.

MUSEOLOGY: SCIENCE OR JUST practical museum work?. Museological Working Papers (MuWop). Estocolmo: Icofom/Statens Historiska Museum, n. 1, 1980.

PADILLA, J. Museus e centros de ciencia en Mexico. In: CRESTANA, S. (Coord.). Educação para a ciência: curso para treinamento em centros e museus de ciência. São Paulo: Livaria da Física, 2001, p. 41-58.

RIVIÈRE, G. H. Définition évolutive de l'écomusée. Museum, XXXVII(4), p. 182-183, 1985.

RÚSSIO, W. G. Texto III. In: ARANTES, A. A. (Org.). Produzindo o passado: estratégias de construção do patrimônio cultural. São Paulo: Brasiliense, 1984, p. 59-78.

Museu, museologia, museólogos e formação. Revista de museologia, São Paulo: Instituto de Museologia de São Paulo Fesp/SP; 1 (1), p. 7-11, 1989.

SAGER, J. C. A practical course in terminology processing. Amsterdam/Philadelhia: John Benjamins Publishing Company, 1990.

SCHÄRER, M. R.Avant-propos/Foreword. ISS, (1), 1995.

SCHEINER,T. C. Museus e museologia. Uma relação científica?. Ciência em museus, (1), p. 59-63, 1989.

. Les multiples facettes de L'Icofom. Cabiers d'étude/Study Series. Comité International de lcom pour la museologie. (8), p. 2-3, 2000.

SOFKA, V. My adventurous live with Icofom, museology, museologists and anti-museologists, giving special reference to Icofom Study Series. Icofom Study Series ISS, v. 1-20, v. 1-19 by Vinos Sofka, v. 20 and reprint edited by Martin R. Schäer. 1, Reprint - International Committee for Museology, p. 1-25, 1995.

Report or preparations of the symposium, Estocolmo, 1983, ISS, n. 2, 1995, p. 2.

Šola, T. Concept et nature de la muséologie. Museum, no. 153, no. 1, 1987, p. 45-49.

STRÁNSKÝ.The theory of systems and museology, MuWoP/DoTraM, n. 2, p. 71-72.

THIVIERGE, M. La muséologie en question. Musées, Printemps 1985.

VAN MENSCH, P.; POUW, P. J. M; SCHOUTEN, F. F. J. Texto apresentado no Colloquium ICTOP/ICOFOM - Londres, julho de 1983; p. 57-65.

VAN MENSCH, P. Museus em movimento. Cadernos museológicos. Rio de Janeiro: Sphan, PróMemória, Ministério da Cultura, p. 49-54, 1989a. estágio seria sistemáticoteorético separando a Museologia do museu; o terceiro comporia os antecedentes num outro nível provendo-a com "qualidade e quantidade" (STRÁNSKÝ,n. 2,p.71-72).

158. Nesse documento Stránský cita também trabalhos seus em que anteriormente procurou resolver a posição da Museologia no sistema das ciências (STRÁNSKÝ, n. 2 , p. 71-72).

159. VAN MENSCH., The structure of museology, 1992.

160. LEWIS. The systematics of museology, its ap plication to Icom's international committees and the role of Icofm. $\mathrm{Mu}$ WoP/DoTraM, n. 2, p. 74.

161. VAN MENSCH. The structure of museology. 1992, 3 de 7 .

162. Id. 1 e 2 de 7.

163.VAN MENSCH, 2000 , p. 20-21.

164. No entanto, não se trata de palavras um dos campos semiológicos pelos quais transitamos (cf. BACCEGA apud CINTRA et al., 1994, p. 9), ou "termos" (palavra e termo são tomados como equivalentes). Do ponto de vista da terminologia, o problema se instala na ausência de percepção de que esses signos lingüísticos estão vinculados a uma concepção global de área, assim a um plano transcendente em que noções fundamentais são representadas com mais rigor, precisão e objetividade e, por possuir tais características, podem ser aplicados universalmente. A terminologia trata do "estudo e campo de atividade relacionados com a coleta, descrição, processamento e apresentação de termos [...], os itens do léxico pertencentes às áreas especializadas de uso de uma ou 
mais linguagens"(SAGER, 1990, p. 2-3)

165. FATTHOUH; SIMENON, 1997, p. 3-5.

166.VAN MENSCH;POUW; SCHOUTEN, 1983, p.59.

167. DESVALLÉES, 2000 p. 8.

168. Conceitos são unidades de pensamento que nomeiam o que se pretende representar, na dependência, para sua consolidação, do consenso de um dado grupo social (SAGER, 1990, p. 22).

169. As palavras, símbolos com significado, realizam em sociedade o caráter simbólico da língua, esta "condição de pensamento" (CINTRA et al., 1994 p. 21-22,35).

170.GRANGER apud CINTRA et al. op. cit., p. 27

171. ÉRI, 1986, p. 110
.The extension of museum concept. MuseumVisie. Special Icom'89 issue, v. 13, p. 20-25, $1989 \mathrm{~b}$.

Towards a methodology of museology. 1992. Tese (Doutorado) - Universidade de Zagreb, Zagreb, 2000, (http:www.xs4all.nl/ rwa/boek01.htm) Museology as a profession. Cabiers d'étude/Study Series. Comité International de Icom pour la museologie,(8), p. 20-21, 2000.

VARINE-BOHAN, H. L'écomusée: au-delà du mot. Museum; 148, XXXVII (4), p. 185, 1985.

VARINE, H. de. A respeito da Mesa-Redonda de Santiago In: ARAÚJO, M. M.; BRUNO, M. C. O. $A$ memória do pensamento museológico contemporâneo. Documentos e depoimentos. Comitê Brasileiro do Icom. São Paulo: FFLCH/USP, 1995. p. 17-19. 